\title{
- Blood pressure as a prognostic factor after acute stroke
}

\author{
Valérie Tikhonoff, Haifeng Zhang, Tom Richart, Jan A Staessen
}

Lancet Neurol 2009; 8: 938-48 Studies Coordinating Centre, Division of Hypertension and Cardiovascular Rehabilitation, Department of Cardiovascular Diseases, University of Leuven, Leuven, Belgium (VTikhonoff MD, H Zhang MD, T Richart MD, J A Staessen MD); Department of Clinical and Experimental Medicine, University of Padova, Padova, Italy (V Tikhonoff); Internal Medicine Unit, General Hospital of Mestre, Venezia, Italy (VTikhonoff); Department of Cardiology, First Affiliated Hospital, Nanjing Medical University, Nanjing, China (H Zhang); and Department of Epidemiology, Maastricht University, Maastricht, Netherlands (T Richart, JA Staessen)

Correspondence to: Jan A Staessen, Department of Epidemiology, Maastricht University, Peter Debyeplein 1, PO Box 616, Maastricht $6200 \mathrm{MD}$, Netherlands

ja.staessen@epid.unimaas.nl

Stroke is the second most common cause of death worldwide and is the complication of hypertension that is most directly linked to blood pressure. Hypertension affects nearly $30 \%$ of the world's population; therefore, reducing blood pressure is key for the prevention of stroke. Unlike the established role of hypertension as a risk factor for stroke, the prognostic importance of blood pressure in determining outcome after acute stroke is unclear. The acute hypertensive response occurs in more than $50 \%$ of all patients with acute stroke and is associated with poor prognosis. The relation between the outcome of acute stroke and blood pressure is U-shaped, with the best outcome at systolic blood-pressure levels ranging from about 140 to $180 \mathrm{~mm} \mathrm{Hg}$. The evidence that decreasing blood pressure in hypertensive patients with acute ischaemic or haemorrhagic stroke improves prognosis needs further confirmation. Whether raising blood pressure to improve perfusion of ischaemic brain areas is beneficial remains even more uncertain. Present guidelines for the management of blood pressure in patients with acute stroke are not evidence-based, but results from ongoing trials might provide more informed recommendations for the future.

\section{Introduction}

Stroke is the second most common cause of death worldwide. ${ }^{1}$ Cerebrovascular disease caused an estimated 5.7 million deaths in 2005 , with $87 \%$ of fatalities occurring in low-income or middle-income countries. ${ }^{2}$ Without intervention, the global number of deaths from stroke is expected to rise to 6.5 million by 2015 and 7.8 million by $2030 .^{2}$ Unlike the established benefit of lowering blood pressure for the primary and secondary prevention of stroke, ${ }^{3}$ the management of hypertension in patients with acute stroke remains controversial because of the paucity of reliable evidence from sufficiently powered randomised clinical trials. Concerns that need to be resolved are whether lowering blood pressure in patients with hypertension might reduce blood flow from collateral vessels to the ischaemic penumbra and lead to loss of neurons or, conversely, whether raising blood pressure in the absence of hypertension might improve the perfusion of ischaemic brain areas without increasing the risk of bleeding.

In this Review, we discuss the emerging data that support management of blood pressure in patients with acute stroke. We first outline the prevalence, underlying mechanisms, and prognostic value of the hypertensive response in acute stroke. We then review the trials investigating the feasibility and safety of management of blood pressure in patients with acute stroke. Lastly, we summarise present guidelines for the management of blood pressure in acute stroke, which are not evidence-based. ${ }^{46}$ The anticipated completion of several ongoing trials might lead to more firm recommendations in the future. ${ }^{4}$

\section{The hypertensive response}

An acute hypertensive response occurs within $24 \mathrm{~h}$ in up to $80 \%$ of patients with acute stroke. This response is an increase of blood pressure above normal (ie, $140 \mathrm{~mm} \mathrm{Hg}$ systolic or $90 \mathrm{~mm} \mathrm{Hg}$ diastolic) or above pre-existing levels in previously hypertensive patients.

\section{Prevalence}

Of the 563704 patients with acute stroke ( $\geq 20$ years of age) who enrolled in the US National Hospital Ambulatory Care Survey, 390584 (69.3\%) had systolic hypertension ( $\geq 140 \mathrm{~mm} \mathrm{Hg}$ ), 172186 (30 . 5\%) had diastolic hypertension ( $\geq 90 \mathrm{~mm} \mathrm{Hg}$ ), and 235843 (41.8\%) had a mean arterial pressure of $107 \mathrm{~mm} \mathrm{Hg}$ or higher. Systolic and mean arterial pressure were increased in all 4245 patients with subarachnoid haemorrhage. ' In 17398 patients with ischaemic stroke randomised in the International Stroke Trial, ${ }^{10}$ mean systolic blood pressure measured within $48 \mathrm{~h}$ of stroke onset was $160 \mathrm{~mm} \mathrm{Hg}$, and 14187 (81.6\%) patients had a systolic blood pressure of $140 \mathrm{~mm} \mathrm{Hg}$ or higher. $^{10}$ In the Chinese Acute Stroke Trial, ${ }^{11}$ $15888(75 \cdot 3 \%)$ patients with acute ischaemic stroke had a systolic blood pressure of $140 \mathrm{~mm} \mathrm{Hg}$ or higher. In a Spanish observational study, ${ }^{12} 844$ patients with ischaemic stroke had their blood pressure measured within $24 \mathrm{~h}$. $265(31.4 \%)$ previously hypertensive patients had a systolic or diastolic blood pressure of at least $160 \mathrm{~mm} \mathrm{Hg}$ or $90 \mathrm{~mm} \mathrm{Hg}$, respectively, and $167(19.8 \%)$ developed new-onset hypertension. ${ }^{12}$

\section{Mechanisms}

The primary cause of the hypertensive response is damage or compression of specific regions in the brain that regulate the activity of the autonomic nervous system. ${ }^{4}$ Pre-existing hypertension, ${ }^{13}$ diabetes mellitus, ${ }^{14}$ high concentrations of serum creatinine,${ }^{14}$ and the Cushing reflex (a reactive increase in blood pressure in response to raised intracranial pressure $)^{15}$ can all exacerbate the rise in blood pressure. Headache, ${ }^{4}$ urine retention, ${ }^{4}$ infection, ${ }^{16}$ and stress associated with admission to hospital can lead to an imbalance in the autonomic nervous system, ${ }^{17}$ activate the sympathetic adrenomedullary pathway, ${ }^{16}$ and raise the concentrations of circulating catecholamines ${ }^{16}$ and inflammatory cytokines, ${ }^{12,16}$ all of which can contribute to the hypertensive response.

Blood pressure tends to decline spontaneously without pharmacological intervention in the first few days to 
weeks after stroke onset. ${ }^{18}$ The change in blood pressure after acute stroke is also associated with the severity of the neurological deficits caused by the stroke..$^{18} \mathrm{~A}$ low to normal blood pressure after acute stroke usually indicates extensive brain damage or concurrent coronary artery heart disease. ${ }^{8,10}$

\section{Risk associated with the hypertensive response}

The hypertensive response in patients with acute stroke is an independent predictor of outcome. In this section, we separately review the role of blood pressure at the onset of stroke as a predictor of outcome for patients with ischaemic or haemorrhagic stroke.

\section{Ischaemic stroke}

A quantitative overview of 32 studies included 10892 patients with acute stroke (onset <7 days). Follow-up of patients varied substantially, from 6 days to 6 years, although most investigators chose to measure outcome at discharge from hospital. In all patients, an increased mean arterial pressure (odds ratio [OR] 1.6; 95\% CI 1.1-2.3) and a high diastolic blood pressure (1.7; $1 \cdot 3-2 \cdot 5)$ were associated with death. In patients with ischaemic stroke, the average increases in blood pressure associated with death or dependency were $11.7 \mathrm{~mm} \mathrm{Hg}$ (95\% CI 1.3-22.2; $\mathrm{p}=0.03$ ) for systolic, $6.0 \mathrm{~mm} \mathrm{Hg}$ $(0.2-11.8 ; \mathrm{p}=0.04)$ for diastolic, and $9.0 \mathrm{~mm} \mathrm{Hg}$ $(0 \cdot 9-17 \cdot 1 ; p=0 \cdot 03)$ for mean arterial pressure. In the GENIC study (Étude du Profil Génétique de l'Infarctus Cérébral), ${ }^{19}$ high systolic blood pressure on admission predicted a poor outcome at 10 days and 6 months, which was independent of baseline risk factors but not of the severity of the initial event.

In some studies of ischaemic stroke, ${ }^{20,21}$ the exclusion of patients with a strongly increased blood pressure on admission weakened the association between blood pressure and outcome. The TOAST study (Trial of ORG 10172 in Acute Stroke Treatment) ${ }^{20}$ did not enrol patients with a mean arterial pressure above $130 \mathrm{~mm} \mathrm{Hg}$. Blood pressure was analysed as a continuous variable. A poor outcome, assessed 90 days after the event, was a Glasgow outcome scale score above 2, a modified Barthel index below 12, or death. In 1281 patients, higher systolic blood pressure on admission (mean $154 \mathrm{~mm} \mathrm{Hg}$ ), but not higher diastolic (mean $85 \mathrm{~mm} \mathrm{Hg}$ ) or mean arterial pressure (mean $108 \mathrm{~mm} \mathrm{Hg}$ ), predicted a poor outcome. The association with systolic blood pressure lost significance after adjustment for other known prognostic factors. The ORs, expressing the risk associated with a $10 \mathrm{~mm} \mathrm{Hg}$ higher systolic blood pressure, were 1.09 (95\% CI 1.03-1.15; $\mathrm{p}=0.003)$ unadjusted and 1.01 $(0 \cdot 93-1 \cdot 09 ; \mathrm{p}=0 \cdot 82)$ adjusted..$^{20}$

Among the 615 participants in the ECASS-I trial (the first European Cooperative Acute Stroke Study), ${ }^{21}$ patients with ischaemic stroke who had higher blood pressure on admission showed better functional recovery at 90 days (modified Rankin scale score of 0 to 1 ). The adjusted ORs associated with a $10 \mathrm{~mm} \mathrm{Hg}$ higher blood pressure were 0.74 (95\% CI $0.61-0.90 ; \mathrm{p}=0.002)$ systolic and 0.61 $(0 \cdot 41-0 \cdot 90 ; \mathrm{p}=0 \cdot 013)$ diastolic. ECASS-I did not enrol patients with an admission blood pressure higher than $185 \mathrm{~mm} \mathrm{Hg}$ systolic or $110 \mathrm{~mm} \mathrm{Hg}$ diastolic. In a recently published series of 565 consecutive Japanese patients with ischaemic stroke, ${ }^{22}$ the systolic blood pressure from 12 to $36 \mathrm{~h}$ after admission ( $\mathrm{p}=0.003$ to $0 \cdot 043$ ), but not at $6 \mathrm{~h}(\mathrm{p}=0.46)$, independently predicted neurological deterioration, defined as an increase of 2 points or more in the National Institutes of Health stroke scale score at 3 weeks, particularly in patients with a cardioembolic stroke. On admission, mean systolic blood pressure was about $165 \mathrm{~mm} \mathrm{Hg}$ and dropped by $5-10 \mathrm{~mm} \mathrm{Hg}$ during the first $36 \mathrm{~h}$ of hospitalisation. In a Palestinian study of 186 patients, hypertension predicted in-hospital mortality equally in 95 women and 91 men with acute stroke $\left(\mathrm{p}=0 \cdot 12\right.$ for women $v$ s men). ${ }^{23}$

Data from several studies ${ }^{10,24}$ have reported a U-shaped association between systolic blood pressure on admission and outcome after stroke. In the International Stroke Trial, ${ }^{10}$ which included 17398 patients with confirmed ischaemic stroke, for every $10 \mathrm{~mm} \mathrm{Hg}$ below $150 \mathrm{~mm} \mathrm{Hg}$ on admission, the risk of early death (within 2 weeks of the qualifying event) and death and dependency at 6 months increased by $17.9 \%(\mathrm{p}<0.0001)$ and $3.6 \%$ $(\mathrm{p}=0 \cdot 044)$, respectively. For every $10 \mathrm{~mm} \mathrm{Hg}$ above $150 \mathrm{~mm} \mathrm{Hg}$, the risk of early death increased by $3.8 \%$ $(\mathrm{p}=0 \cdot 016)$ with a non-significant increase of death or dependency at 6 months $(p=0 \cdot 21)$. The rate of recurrent ischaemic stroke within 14 days increased linearly by 4. $2 \%$ for every $10 \mathrm{~mm} \mathrm{Hg}$ increase in systolic blood pressure at baseline $(p=0 \cdot 023)$. The most favourable outcome at 14 days and at 6 months was for systolic levels ranging from 140 to $179 \mathrm{~mm} \mathrm{Hg}$ at entry. ${ }^{10}$

In a study of 2101 Japanese patients admitted to hospital on the day of stroke onset (1004 ischaemic strokes, 1097 patients with primary intracerebral haemorrhage), ${ }^{24}$ low ( $\leq 130 \mathrm{~mm} \mathrm{Hg}$ ) and high ( $\geq 210 \mathrm{~mm} \mathrm{Hg}$ ) systolic blood pressure after an ischaemic stroke were associated with mortality within 30 days. The adjusted ORs expressing the risk of mortality versus $150-169 \mathrm{~mm} \mathrm{Hg}$ were 2.42 (95\% CI 1.28-4.59; $\mathrm{p}=0 \cdot 007)$ for $\leq 130 \mathrm{~mm} \mathrm{Hg}$ and 1.72 $(0 \cdot 82-3 \cdot 64 ; \mathrm{p}=0 \cdot 15)$ for $\geq 210 \mathrm{~mm} \mathrm{Hg}$. The nadir of the association with mortality in patients with ischaemic stroke was at $140 \mathrm{~mm} \mathrm{Hg}$ in patients who were previously normotensive and at $160 \mathrm{~mm} \mathrm{Hg}$ in patients with a history of hypertension.

Finally, the investigators of SITS-ISTR (Safe Implementation of Thrombolysis in Stroke-International Stroke Thrombolysis Register) recently published a retrospective analysis of the outcome of 10812 patients with acute stroke treated with alteplase. ${ }^{25}$ In multivariable-adjusted analyses, systolic blood pressure (2-24 h after treatment with alteplase) as a continuous variable (mean $151 \mathrm{~mm} \mathrm{Hg}$ ) predicted a worse outcome $(\mathrm{p}<0 \cdot 001)$. As a categorical variable, systolic blood pressure had a linear association 
with symptomatic haemorrhage and a U-shaped association with mortality and dependence at 3 months: a systolic blood pressure of 141-150 $\mathrm{mm} \mathrm{Hg}$ was associated with the most favourable outcomes $(\mathrm{p}<0 \cdot 05) .^{25}$

\section{Haemorrhagic stroke}

In patients with primary intracerebral haemorrhage included in the quantitative overview of 32 studies mentioned in the previous section, ${ }^{7}$ high systolic pressure (OR 2.7; 95\% CI 1.1-6.4) and high diastolic pressure (4.7; 1.9-11.7) were associated with death and dependency. Among 3938 Chinese patients hospitalised on the day of stroke onset (1760 with primary intracerebral haemorrhage, 2178 with acute ischaemic stroke), the in-hospital case-fatality rate was higher for haemorrhagic stroke than for ischaemic stroke (5.9\% vs 1.8\%), whereas the opposite was the case for the disability rate (34.4\% vs $41 \cdot 3 \%) .{ }^{26}$ In patients with haemorrhagic stroke, the probability of death, disability, or both endpoints combined increased with high systolic and diastolic blood pressure on admission. ${ }^{26}$ For example, compared with patients with haemorrhagic stroke with a systolic blood pressure less than $140 \mathrm{~mm} \mathrm{Hg}$, the multivariable-adjusted odds ratios for death or disability assessed during hospitalisation were 1.38 (95\% CI 0.96-1.99), 1.42 (1.00-2.03), 1.84 (1.28-2.64), and $1.91(1 \cdot 35-2 \cdot 70)$ among patients with a systolic blood pressure of 140-159, 160-179, 180-199, and at least $200 \mathrm{~mm} \mathrm{Hg}$, respectively ( $<<0 \cdot 0001$ for linear trend). ${ }^{26}$ In 1097 patients with intracerebral haemorrhage enrolled in the Japanese study, ${ }^{24}$ the ORs for mortality within 30 days were $1.45(95 \%$ CI $0 \cdot 81-2 \cdot 62 ; \mathrm{p}=0 \cdot 21)$ for $\leq 149 \mathrm{~mm} \mathrm{Hg}$ and $2.50 \quad(95 \%$ CI $1.46-4.28 ; \quad \mathrm{p}=0.0008)$ for 210-229 $\mathrm{mm} \mathrm{Hg}$, compared with a blood pressure of 150-169 $\mathrm{mm} \mathrm{Hg}$ at entry.

\section{Management of blood pressure in patients with acute stroke}

A working group of the International Society of Hypertension has summarised the research questions that need to be resolved. ${ }^{8}$ First, in acute ischaemic stroke, should blood pressure be lowered in patients with hypertension or should it be raised when there is evidence of hypoperfusion? Second, should blood pressure be lowered in primary intracerebral haemorrhage? Third, in patients previously treated for hypertension, should drug treatment to reduce blood pressure be continued or should it be stopped? In this section, we summarise the fragmentary evidence in favour of managing blood pressure in patients with acute stroke. Most completed trials only studied the feasibility and safety of controlling blood pressure in acute stroke rather than the long-term outcomes associated with such intervention.

\section{Increasing blood pressure in patients with ischaemic stroke}

The ischaemic penumbra (figure 1) is an area of brain around infarcted tissue, in which there is no electrical activity, with a flat electroencephalographic signal, but where the tissue remains viable, as indicated by the absence of ion pump failure. ${ }^{27}$ Acute stroke impairs the autoregulation of the cerebral circulation (figure 1), so that cerebral blood flow in the ischaemic area becomes passively dependent on mean arterial pressure. ${ }^{4}$ In eight of 48 screened patients with ischaemic stroke, Olsen and co-workers ${ }^{28}$ identified a non-infarcted low-flow area, where an induced increase in blood pressure improved blood flow, as assessed by scintigraphy. Similarly, results from animal experiments have shown that inducing hypertension and expanding the circulating volume can reduce focal cerebral injury. ${ }^{29,30}$ The increased blood pressure opens collateral vessels and improves perfusion of the ischaemic penumbra. These observations support the hypothesis that increasing blood pressure in acute ischaemic stroke might improve prognosis.

In 2006, Mistri and colleagues ${ }^{31}$ undertook a systematic review of publications on pressor therapy in stroke. These authors did not find any articles on haemorrhagic stroke, but they identified 12 relevant publications ${ }^{32-43}$ on acute ischaemic stroke, which included 319 patients (54\% women; mean age range $42-88$ years). The pressor drugs used were phenylephrine, ${ }^{33,34,37-40}$ norepinephrine, ${ }^{42,43}$ epinephrine, ${ }^{32}$ dobutamine, ${ }^{35}$ dopamine, ${ }^{41}$ and diaspirin cross-linked haemoglobin. ${ }^{36}$ Phenylephrine was the most commonly used drug (62 of 194 patients). ${ }^{33,34,37-40}$ A meta-analysis was impossible, ${ }^{31}$ because of the small number of patients and events and because of varying entry and outcome criteria. Nevertheless, this narrative overview of publications ${ }^{31}$ led to the preliminary conclusion that pressor therapy in acute ischaemic stroke seemed feasible and well tolerated, but that the benefit and risk in terms of clinical outcomes remained to be elucidated.

In a retrospective, non-randomised study, ${ }^{44} 54$ patients with acute ischaemic stroke received standard therapy, 46 received induced-hypertension therapy, and all patients underwent perfusion MRI within 7 days of the event. Compared with the standard-therapy group, more patients with induced hypertension ( $80 \%$ vs $28 \%$ ) had a greater than $70 \%$ stenosis or occlusion of large intracranial or extracranial arteries. Otherwise, the baseline characteristics of the two groups were similar. The patients with induced hypertension had a trend towards higher mean arterial pressure compared with the control group during the first 2 days, which reached significance on the third day (103 vs $96 \mathrm{~mm} \mathrm{Hg} ; \mathrm{p}=0 \cdot 02$ ). Only $35 \%$ of patients with induced hypertension met the goal of augmentation of mean arterial pressure by $10-20 \%$ above baseline. All patients survived to discharge. Two patients in the inducedhypertension group had intracerebral haemorrhage compared with none in the control group. Two patients in the standard-therapy group, but no patient in the inducedhypertension group, had myocardial ischaemia. In line with Mistri's overview, ${ }^{31}$ Koenig and co-workers ${ }^{44}$ concluded that increasing blood pressure in patients with acute ischaemic stroke is relatively safe. 
In the pressor arm of the CHHIPS (Controlling Hypertension and Hypotension Immediately Post-Stroke) trial, ${ }^{45,46}$ the investigators intended to use phenylephrine to raise blood pressure in patients with acute ischaemic stroke and a systolic blood pressure below $140 \mathrm{~mm} \mathrm{Hg}$ (table 1). Of 2267 patients admitted with acute stroke to the participating centres and screened for entry into the CHHIPS trial, only ten $(0 \cdot 44 \%)$ qualified for the pressor arm. Of these ten patients, three were not randomised (for unclear reasons) and seven presented after the pressor arm had been discontinued because of the low recruitment.

\section{Reducing blood pressure in patients with acute stroke}

In this section we describe the effects of lowering blood pressure in trials that included patients with ischaemic stroke and haemorrhagic stroke, as well as the effects in trials that enrolled patients with a specific stroke subtype.

\section{Ischaemic stroke}

The ACCESS (Acute Candesartan Cilexetil Therapy in Stroke Survivors) study was a double-blind, placebo-controlled, phase 2 pilot trial in patients with a motor deficit caused by cerebral ischaemia.,48 Patients randomly received placebo or candesartan 4-16 mg per day for 7 days after admission. The primary endpoint was death or disability at 3 months after the randomised period. $^{48}$ Blood pressure at randomisation averaged $189 \mathrm{~mm} \mathrm{Hg}$ systolic and $99 \mathrm{~mm} \mathrm{Hg}$ diastolic. On day 7, all patients were either started or continued on candesartan with the possible addition of hydrochlorothiazide, felodipine, or metoprolol, as necessary, to achieve a blood pressure below $140 \mathrm{~mm} \mathrm{Hg}$ systolic and $90 \mathrm{~mm} \mathrm{Hg}$ diastolic or a daytime ambulatory blood pressure below $135 \mathrm{~mm} \mathrm{Hg}$ and $85 \mathrm{~mm} \mathrm{Hg}$. After randomisation of 342 of 500 scheduled patients, of whom 339 were analysable, the trial was stopped because of an unspecified imbalance in endpoints. ${ }^{48}$ During the placebo-controlled phase, in the first 7 days, blood-pressure levels were reportedly similar in both groups. At the end of the initial 7-day period, all but two patients in the control group and an unreported number in the candesartan group had a mean daytime blood pressure greater than $135 \mathrm{~mm} \mathrm{Hg}$ systolic or $85 \mathrm{~mm} \mathrm{Hg}$ diastolic. ${ }^{48}$ During open-label treatment, blood pressure also remained similar in the two groups. Thus, the ACCESS results are difficult to interpret. The report did not provide detailed information on antihypertensive treatment before randomisation, on the use of intravenous urapidil when blood-pressure thresholds for safety were exceeded during the 7-day randomised period, or on the use of concomitant antihypertensive drugs during long-term follow-up. The graphical representation of the blood-pressure results in the ACCESS report ${ }^{48}$ suggests that the difference in systolic blood pressure between the two groups on days 6 and 7 of randomised treatment might have been as large as $5-10 \mathrm{~mm} \mathrm{Hg}$. Figure 2 shows that in unadjusted analyses after 400 days, the cumulative event

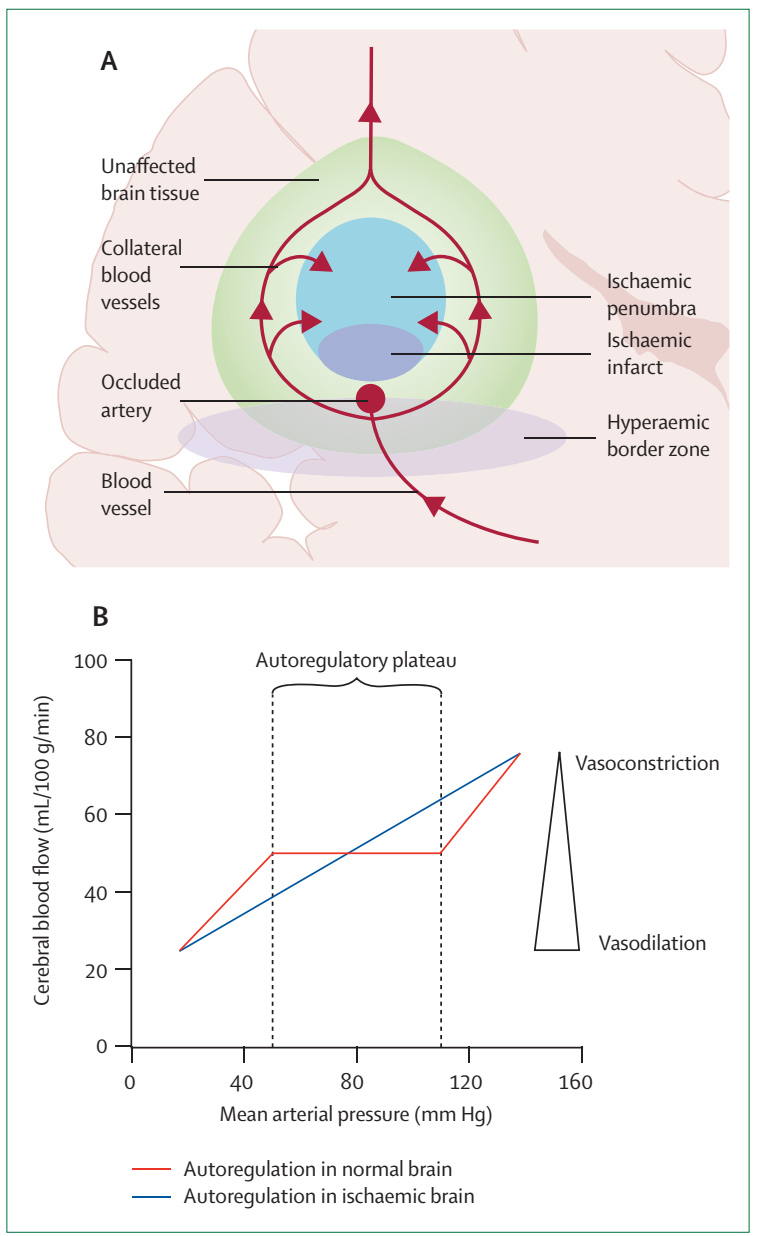

Figure 1: Blood flow in ischaemic and normal brain tissue

(A) Regional blood flow surrounding an infarct. Upstream of the occluded artery, acidosis and vasoactive metabolites give rise to a hyperaemic border zone. Downstream of the occlusion, in the ischaemic penumbra, the perfusion pressure is too low for acidosis and metabolites to induce hyperaemia. The infarcted core indicates irreversibly injured brain tissue. The ischaemic penumbra consists of viable tissue that can be rescued if blood flow is restored. (B) Cerebral blood flow in normal and ischaemic brain tissue. Autoregulation depends on vasoactive tone and maintains a steady blood flow through normal brain tissue independent of the perfusion pressure, whereas blood flow in ischaemic brain tissue is proportional to the perfusion pressure.

rate was $53 \%$ lower $(\mathrm{p}=0 \cdot 026)$ in patients who had received candesartan compared with those who had received placebo during the initial 7 days. However, the KaplanMeier estimates (figure 2) also show that at 3 months, corresponding to the timing of the prespecified primary endpoint, ${ }^{48}$ the number of events in the two groups was similar. Table 2 shows the secondary endpoints.

\section{Ischaemic stroke and haemorrhagic stroke}

The BASC (Blood Pressure in Acute Stroke Collaboration) investigators published a quantitative overview of the effects of vasoactive drugs on blood pressure in patients with ischaemic or haemorrhagic stroke. ${ }^{55}$ This overview included 32 trials and 5368 patients..$^{55}$ Calcium-channel blockers (CCBs) given intravenously $(n=389)$ lowered 
systolic blood pressure by $8 \cdot 2 \mathrm{~mm} \mathrm{Hg}(95 \%$ CI 3 - 8-12 - 6) and diastolic blood pressure by $6 \cdot 7 \mathrm{~mm} \mathrm{Hg}(4 \cdot 3-9 \cdot 2)$; CCBs given orally $(n=2123)$ lowered systolic blood pressure by $3.2 \mathrm{~mm} \mathrm{Hg}(1 \cdot 3-5 \cdot 0)$ and diastolic blood pressure by $2 \cdot 0 \mathrm{~mm} \mathrm{Hg}(1 \cdot 0-3 \cdot 0)$. $\beta$ blockers $(n=338)$ lowered diastolic blood pressure by $4.5 \mathrm{~mm} \mathrm{Hg}(1 \cdot 2-7 \cdot 8)$, but the induced $5.0 \mathrm{~mm} \mathrm{Hg}$ decrease in systolic blood pressure was not significant $(n=33 ;-0 \cdot 4$ to $10 \cdot 2)$. Angiotensin-converting enzyme inhibitors nonsignificantly reduced systolic blood pressure by $5.4 \mathrm{~mm} \mathrm{Hg} \mathrm{(-5.8} \mathrm{to} 16 \cdot 5)$ and diastolic blood pressure by $3.0 \mathrm{~mm} \mathrm{Hg}(-5 \cdot 0$ to $11 \cdot 1)$. None of the drug classes significantly altered outcome apart from $\beta$ blockers, ${ }^{56}$ which increased the early case-fatality rate (OR 1.77; 95\% CI 1.05-3.00). ${ }^{55}$ In summary, CCBs, $\beta$ blockers, and, probably, angiotensin-converting enzyme inhibitors lowered blood pressure in patients with acute stroke, but the reviewed data gave no reliable information on the clinical outcomes associated with this decrease in blood pressure. In two small trials $(n=127)$ of transdermal glyceryl trinitrate, ${ }^{57,58}$ this nitric oxide donor lowered $24 \mathrm{~h}$ systolic blood pressure by $7.9 \mathrm{~mm} \mathrm{Hg}\left(95 \% \mathrm{CI} \mathrm{0} \mathrm{-} \mathrm{1-15} \mathrm{·} \mathrm{8),}{ }^{59}\right.$ but had no significant effect on death, deterioration, or dependency. ${ }^{59}$ Thiazide diuretics are not effective in lowering blood pressure in the immediate ${ }^{60}$ and subacute post-stroke ${ }^{61}$ period in patients with ischaemic stroke.

The depressor arm of the CHHIPS trial (table 1$)^{45,49}$ involved 179 patients (mean age 74 years) who had cerebral infarction or haemorrhage and who had a systolic blood pressure over $160 \mathrm{~mm} \mathrm{Hg}$. Within $36 \mathrm{~h}$ of symptom onset, in a double-blind design, patients randomly received oral labetalol, lisinopril, or placebo if they did not have dysphagia, or intravenous labetalol, sublingual lisinopril, or placebo if they had dysphagia. Blood pressure at entry averaged $181 \mathrm{~mm} \mathrm{Hg}$ systolic and
$95 \mathrm{~mm} \mathrm{Hg}$ diastolic. Within the first $24 \mathrm{~h}$, systolic blood pressure fell by $21 \mathrm{~mm} \mathrm{Hg}$ on active treatment and by $11 \mathrm{~mm} \mathrm{Hg}$ on placebo ( $\mathrm{p}=0 \cdot 004)$. The primary outcome, death or dependency at 2 weeks, occurred in 69 patients $(61.1 \%)$ in the active-treatment group and in 35 patients $(59.3 \%)$ in the placebo group. The relative risk (RR) on active versus placebo treatment was 1.03 (95\% CI $0 \cdot 80-1 \cdot 33 ; \mathrm{p}=0 \cdot 82$ ). Active treatment was not associated with early neurological deterioration $(1 \cdot 22$; $0.33-4.54 ; \mathrm{p}=0.76)$ or with an increased incidence of serious adverse events $(0 \cdot 91 ; 0 \cdot 69-1 \cdot 12 ; \mathrm{p}=0 \cdot 50)$. The $60 \%$ decrease $(9.7 \%$ vs $20.3 \%)$ in 3 -month mortality on active treatment just reached significance (hazard ratio $0 \cdot 4 ; 95 \%$ CI $0 \cdot 2-1 \cdot 0 ; p=0 \cdot 05)$. The results from CHHIPS $^{45,46,49}$ indicated that early lowering of blood pressure in hypertensive patients with acute ischaemic or haemorrhagic stroke is safe, but, owing to the small sample size, these findings cannot be generalised.

\section{Intracerebral haemorrhage}

INTERACT (Intensive Blood Pressure Reduction in Acute Cerebral Haemorrhage) ${ }^{50}$ was an open trial with blinded endpoint assessment. This trial involved 404 patients who had acute spontaneous intracerebral haemorrhage diagnosed by CT within $6 \mathrm{~h}$ of onset, increased systolic blood pressure (150-220 $\mathrm{mm} \mathrm{Hg}$ ), and no definite indication or contraindication to treatment with antihypertensive drugs. The patients were randomly assigned to early intensive lowering of systolic blood pressure (target $140 \mathrm{~mm} \mathrm{Hg}$ ) or standard guideline-based management of systolic blood pressure (target $180 \mathrm{~mm} \mathrm{Hg}$ ). Compared with the standard-management group, systolic blood pressure was lower in the intensive-treatment group by $13.3 \mathrm{~mm} \mathrm{Hg}(95 \% \mathrm{CI} 8 \cdot 9-17 \cdot 6)$ during the first hour and by $10 \cdot 8 \mathrm{~mm} \mathrm{Hg}(7 \cdot 7-13 \cdot 9)$ during the next $23 \mathrm{~h}$ (153 vs

\begin{tabular}{|c|c|c|c|c|c|}
\hline & Design & Drugs & Endpoints & Entry criteria & Sample size \\
\hline ACCESS* $^{*}(1998-2003)^{47,48}$ & $\begin{array}{l}\text { Randomised, double-blind, } \\
\text { placebo-controlled }\end{array}$ & Candesartan vs placebo & $\begin{array}{l}\text { Predefined: death or disability at } 3 \text { months } \\
\text { Post hoc: death, cerebrovascular events, } \\
\text { and cardiovascular events at } 400 \text { days } \\
\text { (figure 2) }\end{array}$ & $\begin{array}{l}\text { IS, motor deficit, age }<85 \text { years, } \\
\mathrm{BP} \geq 200 / \geq 110 \mathrm{~mm} \mathrm{Hg} \text { after } \\
6-24 \mathrm{~h} \text { or } \geq 180 / \geq 105 \mathrm{~mm} \mathrm{Hg} \\
\text { after } 24-36 \mathrm{~h}\end{array}$ & $\begin{array}{l}\text { Planned: } 500 \\
\text { Actual: } 339 \\
\text { Published }\end{array}$ \\
\hline CHHIPS $(2004-2008)^{45,46,49}$ & $\begin{array}{l}\text { Randomised, double-blind, } \\
\text { placebo-controlled, } \\
\text { titrated dose }\end{array}$ & $\begin{array}{l}\text { Depressor arm: lisinopril or } \\
\text { labetalol vs placebo } \\
\text { Pressor arm: phenylephrine vs } \\
\text { placebo }\end{array}$ & $\begin{array}{l}\text { Primary: death or dependency at } 2 \text { weeks } \\
\text { Secondary: BP at } 24 \mathrm{~h} \text {, functional status, } \\
\text { stroke recurrence, BP at } 2 \text { weeks, quality of } \\
\text { life at } 3 \text { months }\end{array}$ & $\begin{array}{l}\text { Depressor arm: stroke }(<12 \mathrm{~h}) \\
\text { and systolic BP }>160 \mathrm{~mm} \mathrm{Hg} \\
\text { Pressor arm: IS }(<12 \mathrm{~h}) \text { and } \\
\text { systolic BP }<140 \mathrm{~mm} \mathrm{Hg} \\
\text { Both: age }>18 \text { years }\end{array}$ & $\begin{array}{l}\text { Planned: } 2000 \\
\text { Actual: } 179 \\
\text { Published }\end{array}$ \\
\hline INTERACT $(2005-2007)^{50,51}$ & $\begin{array}{l}\text { Randomised, open-label, } \\
\text { blinded endpoints }\end{array}$ & $\begin{array}{l}\text { Usual treatment to lower } \\
\text { systolic BP to }<180 \mathrm{~mm} \mathrm{Hg} \mathrm{vs} \\
\text { intensive treatment to lower } \\
\text { systolic BP to }<140 \mathrm{~mm} \mathrm{Hg}\end{array}$ & $\begin{array}{l}\text { Primary: proportional change in } \\
\text { haematoma volume (within } 24 \mathrm{~h} \text { ) } \\
\text { Secondary: haematoma volume, adverse } \\
\text { events, and clinical outcomes (up to } \\
90 \text { days) }\end{array}$ & $\begin{array}{l}\mathrm{HS}(<6 \mathrm{~h}), \text { age }>18 \text { years, } \\
\text { systolic BP } 150-220 \mathrm{~mm} \mathrm{Hg}\end{array}$ & $\begin{array}{l}\text { Planned: } 400 \\
\text { Actual: } 404 \\
\text { Published }\end{array}$ \\
\hline ATACH $(2005-2008)^{52-54}$ & $\begin{array}{l}\text { Non-randomised, open- } \\
\text { label, uncontrolled }\end{array}$ & $\begin{array}{l}\text { Nicardipine to lower BP to } \\
170-200,140-170 \text {, or } \\
110-140 \mathrm{~mm} \mathrm{Hg}\end{array}$ & $\begin{array}{l}\text { Tolerability and safety without } \\
\text { neurological deterioration or adverse } \\
\text { events }\end{array}$ & $\begin{array}{l}\mathrm{HS}(<12 \mathrm{~h}), \text { age }>18 \text { years, } \\
\text { systolic BP }>170 \mathrm{~mm} \mathrm{Hg}\end{array}$ & $\begin{array}{l}\text { Planned: } 60 \\
\text { Actual: } 124 \\
\text { Completed } \\
\text { (abstract published }{ }^{53} \text { ) }\end{array}$ \\
\hline
\end{tabular}


$167 \mathrm{~mm} \mathrm{Hg}$ and 146 vs $157 \mathrm{~mm} \mathrm{Hg}$, respectively). Mean proportional haematoma growth was $36.3 \%$ in the group managed according to the guidelines and $13.7 \%$ in the intensive-treatment group. The $22.6 \%$ difference (95\% CI $0 \cdot 6-44 \cdot 5 \% ; p=0 \cdot 04)$ was significant at $24 \mathrm{~h}$. Intensive lowering of systolic blood pressure did not alter the risks of adverse events up to 90 days. The results from INTERACT indicated that early intensive lowering of blood pressure in haemorrhagic stroke is clinically feasible, well tolerated, and probably reduces haematoma growth. However, these results need confirmation in a full-scale trial in a wide range of patients with spontaneous intracerebral haemorrhage.

In ATACH (Antihypertensive Treatment in Acute Cerebral Hemorrhage), an open-label trial, ${ }^{52,53}$ the effects of nicardipine to control systolic blood pressure were investigated in three escalating tiers: tier 1, to reduce blood pressure to $170-200 \mathrm{~mm} \mathrm{Hg}$; tier 2, to reduce blood pressure to $140-170 \mathrm{~mm} \mathrm{Hg}$ in patients who were treated successfully in tier 1; and tier 3, to reduce blood pressure to $110-140 \mathrm{~mm} \mathrm{Hg}$ in patients who were treated successfully in tier 2. This pilot study has been completed and reported in abstract form, ${ }^{53}$ but is not yet published. ATACH confirmed the safety of tight control of blood pressure in patients with intracerebral haemorrhage.

\section{Subarachnoid haemorrhage}

In 2007, a Cochrane review ${ }^{62}$ assessed whether CCBs improve the outcome of patients with aneurysmal subarachnoid haemorrhage. This overview included 3361 patients randomised into 16 controlled clinical trials. In three studies, patients received magnesium sulphate in addition to nimodipine. Overall, CCBs reduced the risk of poor outcome, with a relative risk (RR) of 0.81 (95\% CI $0.72-0.92)$; the number needed to treat was 19 (1-51). For oral nimodipine alone (about 170-540 mg per day for 3 weeks), the RR was 0.67 $(0 \cdot 55-0 \cdot 81)$. For other CCBs or intravenous nimodipine, the results were not significant. CCBs reduced the occurrence of secondary ischaemia (RR 0 66; 0 - 59-0 - 75) and showed a favourable trend for case fatality $(0 \cdot 87$; $0 \cdot 73-1 \cdot 02)$. The authors concluded that CCBs reduced the risk of a poor outcome and secondary ischaemia after aneurysmal subarachnoid haemorrhage. However, these favourable results depended mainly on one large trial of oral nimodipine. ${ }^{63}$ The evidence for other CCBs was inconclusive. Given the evidence for benefit and the low risk, oral nimodipine might be indicated in patients with aneurysmal subarachnoid haemorrhage. Intravenous administration of CCBs, however, cannot be recommended for routine use in such patients. ${ }^{62}$

At present, nimodipine is the only CCB licensed to prevent vasospasm, to reduce the incidence and extent of ischaemic deficits, and to improve neurological outcomes in patients with aneurysmal subarachnoid haemorrhage. Nicardipine is a second-generation dihydropyridine-type

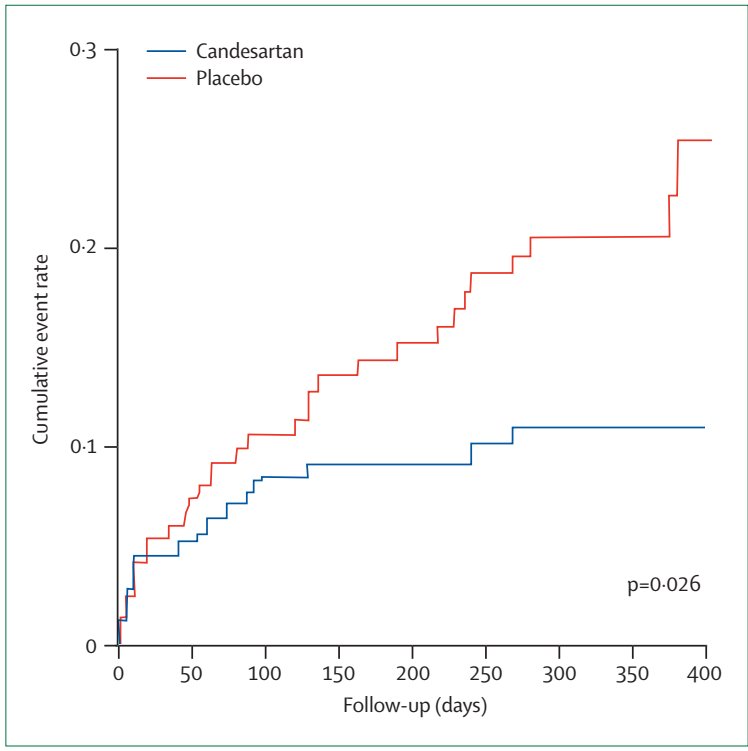

Figure 2: Kaplan-Meier survival function estimates for the primary endpoint in the ACCESS trial

The primary endpoint consisted of death and disability 3 months after the end of the 7-day randomised period (candesartan 4-16 mg per day vs placebo). ${ }^{48}$ ACCESS=Acute Candesartan Cilexetil Therapy in Stroke Survivors.

\begin{tabular}{|lcc|}
\hline & Placebo $(\mathbf{n = 1 6 6 )}$ & Candesartan $(\mathbf{n = 1 7 3 )}$ \\
\hline 12-month mortality & $12(7 \cdot 2)$ & $5(2 \cdot 9)$ \\
Vascular events & $31(18 \cdot 7)$ & $17(9 \cdot 8)$ \\
Cardiovascular events & $10(6 \cdot 0)$ & $2(1 \cdot 2)$ \\
Cerebrovascular events & $19(11 \cdot 4)$ & $13(7 \cdot 5)$ \\
Non-cardiovascular events & $1(0 \cdot 6)$ & $1(0 \cdot 6)$ \\
Pulmonary embolism & $1(0 \cdot 6)$ & $1(0 \cdot 6)$ \\
Data are $n$ (\%). ACCESS=Acute Candesartan Cilexetil Therapy in Stroke Survivors trial. \\
\hline Table 2: Secondary endpoints of the ACCESS trial ${ }^{48}$
\end{tabular}

CCB with high vascular selectivity and strong cerebral vasodilatory activity. ${ }^{64}$ According to a recently published narrative review, ${ }^{65}$ nicardipine given intra-arterially or via prolonged-release implants might be an effective alternative to nimodipine.

\section{Management of previously treated hypertensive patients with acute stroke}

Whether ongoing therapy to lower blood pressure should be continued or stopped in patients with acute stroke still needs to be resolved by proper evidence from randomised clinical trials. The SITS-ISTR investigators ${ }^{25}$ recently published a retrospective non-randomised analysis, which indicated that withholding antihypertensive therapy for up to 7 days after an ischaemic event in patients with a history of hypertension was associated with a worse outcome, whereas initiation of antihypertensive therapy in newly recognised moderate hypertension was associated with a favourable outcome..$^{25}$ 


\section{Ongoing trials}

Table 3 provides details on four ongoing trials set up to assess the feasibility and safety of reducing blood pressure in patients with acute stroke. Table 4 lists the ongoing outcome trials in patients with acute stroke. The rationale and design characteristics of COSSACS (Continue Or Stop Post-Stroke Antihypertensives Collaborative Study) ${ }^{70}$ and ENOS (Efficacy of Nitric Oxide in Stroke) ${ }^{71}$ have been published. Directories of ongoing trials of intervening with blood pressure in patients with acute stroke are available online ${ }^{69}$ and in printed format. ${ }^{75}$

\section{Guidelines for blood-pressure management during acute stroke}

Current guidelines ${ }^{76-85}$ on the management of hypertension in patients with acute stroke (webappendix) are not evidence-based. ${ }^{46}$ The present recommendation is to not treat hypertension in most patients with ischaemic stroke, unless blood pressure exceeds $200 \mathrm{~mm} \mathrm{Hg}^{71}$ to $220 \mathrm{~mm} \mathrm{Hg}^{76-78,80,82-85}$ (systolic) or $120 \mathrm{~mm} \mathrm{Hg}^{76-78,80,82-85}$ to $140 \mathrm{~mm} \mathrm{Hg}$ (diastolic). ${ }^{7,82,84}$ Alteplase should only be given if the blood pressure is lower than $185 \mathrm{~mm} \mathrm{Hg}$

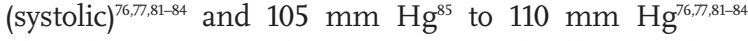
(diastolic). Patients with primaryintracerebral haemorrhage can be treated with antihypertensive drugs if systolic blood pressure is higher than $180 \mathrm{~mm} \mathrm{Hg}^{76,79}$ to $200 \mathrm{~mm} \mathrm{Hg}^{79,81}$ if diastolic blood pressure exceeds $105 \mathrm{~mm} \mathrm{Hg}$, ${ }^{76}$ or if mean arterial pressure is higher than $130 \mathrm{~mm} \mathrm{Hg} \mathrm{Hg}^{7,79,80}$ to $150 \mathrm{~mm} \mathrm{Hg.}{ }^{79}$ Current guidelines do not support interventions to increase blood pressure in patients with acute ischaemic stroke.

In patients with acute stroke, blood pressure should be reduced gradually with special attention for possible contraindications. The decrease in blood pressure should not exceed $10-20 \%$ of the initial level because of the higher set point of the autoregulation of cerebral blood flow in hypertensive patients and to avoid the risk of poor perfusion of affected brain area. ${ }^{80,83}$ In case of occlusive or severely stenotic atherosclerotic disease of the main arteries that sustain blood flow to the brain, decreasing blood pressure can cause cerebral ischaemia, particularly when the collateral circulation is impaired (eg, owing to an incomplete or hypofunctional circle of Willis or bilateral carotid lesions). ${ }^{86,87}$ In patients with a carotid-artery stenosis of $50 \%$ or more or occlusion of the carotid artery ipsilateral to the infarcted brain, high systolic blood pressure ( $\geq 180 \mathrm{~mm} \mathrm{Hg}$; death rate 2 of 51 [3.9\%]) was associated with lower mortality at 3 months compared with patients with a systolic pressure of $140-179 \mathrm{~mm} \mathrm{Hg}$ (16 of $123[13 \cdot 0 \%]$ ) or less than $140 \mathrm{~mm} \mathrm{Hg}$ (11 of 54 $[20 \cdot 4 \%]) .^{88}$ Indications to actively lower blood pressure are haematoma growth or rebleeding in primary intracerebral haemorrhage, or coexisting critical conditions, such as hypertensive encephalopathy, ${ }^{76,78,81,83,84}$ aortic dissection, ${ }^{76,78,81-84}$ heart failure, ${ }^{7,78,81-84}$ acute myocardial infarction, ${ }^{76,81-84}$ acute renal failure, ${ }^{76,81,84}$ or preeclampsia and eclampsia. ${ }^{81}$

The drug classes recommended for lowering blood pressure in patients with acute stroke are listed in the webappendix. Sodium nitroprusside is probably inappropriate for primary intracerebral haemorrhage because it is a potent antiplatelet drug and can raise intracranial pressure. ${ }^{8}$ Recently, Suri and colleagues ${ }^{89}$ published a retrospective analysis of a hospital discharge database in the USA. Among 12767 patients admitted with a primary diagnosis of intracerebral haemorrhage over 1 year, 926 patients $(7.3 \%)$ received nicardipine and $530(4 \cdot 3 \%)$ patients received nitroprusside intravenously within $24 \mathrm{~h}$ after admission. There were no differences

\begin{tabular}{|c|c|c|c|c|c|}
\hline & Design & Drugs & Endpoints & Entry criteria & Sample size \\
\hline ACCOST $(2004-2008)^{66}$ & $\begin{array}{l}\text { Randomised, double- } \\
\text { blind, placebo-controlled }\end{array}$ & $\begin{array}{l}\text { Candesartan vs } \\
\text { placebo }\end{array}$ & $\begin{array}{l}\text { Total and cardiovascular } \\
\text { mortality ( } 12 \text { months), } \\
\text { recovery ( } 3 \text { months) }\end{array}$ & $\begin{array}{l}\text { IS }(<72 \mathrm{~h}) \text {, age }>18 \text { years, } \\
\mathrm{BP}>120 / 70 \mathrm{~mm} \mathrm{Hg}\end{array}$ & $\begin{array}{l}\text { Planned: } 50 \\
\text { Actual: } 39 \\
\text { Stopped }\end{array}$ \\
\hline BLAST $(2007-2009)^{67}$ & $\begin{array}{l}\text { Randomised, double- } \\
\text { blind, placebo-controlled }\end{array}$ & $\begin{array}{l}\text { Valsartan vs } \\
\text { placebo }\end{array}$ & $\begin{array}{l}\text { Glasgow and Rankin score } \\
\text { (1 month) }\end{array}$ & $\begin{array}{l}\text { IS }(<48 \mathrm{~h}) \text {, age }>18 \text { years, } \\
\text { history of hypertension }\end{array}$ & $\begin{array}{l}\text { Planned: } 20 \\
\text { Study withdrawn } \\
\text { before recruitment }\end{array}$ \\
\hline $\begin{array}{l}\text { CARING } \\
(2004 \text {-ongoing })^{68}\end{array}$ & $\begin{array}{l}\text { Non-randomised, } \\
\text { uncontrolled, } \\
\text { prospective, open-label }\end{array}$ & $\begin{array}{l}\text { Double and triple } \\
\text { concentrated } \\
\text { nicardipine }\end{array}$ & $\begin{array}{l}\text { Rate of peripheral phlebitis, } \\
\text { time and dosage needed to } \\
\text { reach the target BP }\end{array}$ & $\begin{array}{l}\text { Stroke }(\mathrm{IS}, \mathrm{HS} \text {, subarachnoid } \\
\text { haemorrhage }[<48 \mathrm{~h}]) \text {, age } \\
>18 \text { years }\end{array}$ & $\begin{array}{l}\text { Planned: } 50 \\
\text { Actual: } 25 \\
\text { Recruiting }\end{array}$ \\
\hline $\begin{array}{l}\text { ICH ADAPT* }^{*} \\
(2007 \text {-ongoing })^{69}\end{array}$ & $\begin{array}{l}\text { Randomised, open-label, } \\
\text { blinded endpoints }\end{array}$ & $\begin{array}{l}\text { Labetalol vs } \\
\text { treatment according } \\
\text { to ASA guideline }\end{array}$ & $\begin{array}{l}\text { Peri-haematomal regional } \\
\text { CBF measured by } C T \\
\text { perfusion } 2 \text { h after initiation } \\
\text { of BP-lowering treatment; } \\
\text { rate of CBF reduction ( } \geq 15 \% \\
v s<15 \%)\end{array}$ & $\begin{array}{l}\mathrm{HS}(\leq 12 \mathrm{~h}) \text {, age }>18 \text { years, } \\
\text { systolic } \mathrm{BP} \geq 150 \mathrm{~mm} \mathrm{Hg}\end{array}$ & $\begin{array}{l}\text { Planned: } 82 \\
\text { Actual: } 3 \\
\text { Recruiting }\end{array}$ \\
\hline \multicolumn{6}{|c|}{$\begin{array}{l}\text { ACCOST=Acute Candesartan Cilexetil Outcomes Stroke Trial. ASA=American Stroke Association. BLAST=Blood Pressure Lowering in Acute Stroke Trial. BP=blood pressure. } \\
\text { CARING=Nicardipine for the Treatment of Hypertension in Patients with Ischemic Stroke, Intracerebral Hemorrhage or Subarachnoid Hemorrhage. CBF=cerebral blood flow. } \\
\text { HS=haemorrhagic stroke. ICH ADAPT=Intracerebral Hemorrhage Acutely Decreasing Arterial Pressure Trial. IS=ischaemic stroke. *Trial registration number could not be } \\
\text { found. More information is available in reference } 71 \text {. For updated information on trials with registration numbers provided, readers can search using the website or trial } \\
\text { number provided in the reference list. }\end{array}$} \\
\hline
\end{tabular}




\begin{tabular}{|c|c|c|c|c|c|}
\hline & Design & Interventions & Endpoints & Entry criteria & Sample size \\
\hline $\begin{array}{l}\text { COSSACS }^{*} \\
\text { (2002-ongoing) })^{70}\end{array}$ & $\begin{array}{l}\text { Randomised, open-label, } \\
\text { blinded endpoints, age } \\
\text { stratification ( }<75 \text { vs } \\
\geq 75 \text { years) }\end{array}$ & $\begin{array}{l}\text { BP-lowering drugs } \\
\text { continued vs } \\
\text { discontinued within } \\
48 \text { h of stroke onset }\end{array}$ & $\begin{array}{l}\text { Primary: death or dependency at } 2 \text { weeks } \\
\text { Secondary: functional status and BP at } 2 \text { weeks; discharge } \\
\text { destination; death or dependency, stroke recurrence, and } \\
\text { QoL at } 6 \text { months }\end{array}$ & $\begin{array}{l}\text { Stroke }(<24 \mathrm{~h}) \text {, age }>18 \text { years, } \\
\text { receiving antihypertensive } \\
\text { drugs, } \mathrm{BP}<200 /<120 \mathrm{~mm} \mathrm{Hg} \\
\text { (if HS) }\end{array}$ & $\begin{array}{l}\text { Planned: } 2900 \\
\text { Actual: } 573 \\
\text { Recruiting }\end{array}$ \\
\hline ENOS (2001-ongoing) $)^{7,72}$ & $\begin{array}{l}\text { Randomised, single-blind, } \\
\text { blinded endpoints, placebo- } \\
\text { controlled }\end{array}$ & $\begin{array}{l}\text { Transdermal } \\
\text { glyceryl trinitrate vs } \\
\text { placebo }\end{array}$ & $\begin{array}{l}\text { Primary: mortality and Rankin score ( } 3 \text { months) } \\
\text { Secondary: recurrent stroke; deep vein thrombosis, } \\
\text { pulmonary embolism, and intracranial haemorrhage } \\
\text { ( }<7 \text { days); major extracranial haemorrhage ( }<10 \text { days); BP } \\
\text { over } 7 \text { days; length of hospital stay; functional status and } \\
\text { QoL at discharge and at } 3 \text { months }\end{array}$ & $\begin{array}{l}\text { Stroke, age }>18 \text { years, } \\
\text { BP } 140-220 \mathrm{~mm} \mathrm{Hg} \\
\text { Rankin score }>3\end{array}$ & $\begin{array}{l}\text { Planned: } 1300 \\
\text { Actual: } 932 \\
\text { Recruiting }\end{array}$ \\
\hline $\begin{array}{l}\text { INTERACT } 2 \\
(2008 \text {-ongoing })^{73}\end{array}$ & Randomised, open-label & $\begin{array}{l}\text { Intravenous BP- } \\
\text { lowering drugs vs } \\
\text { treatment according } \\
\text { to ASA guidelines }\end{array}$ & $\begin{array}{l}\text { Primary: death and dependency ( } 3 \text { months) } \\
\text { Secondary: neurological deterioration }(<72 \mathrm{~h} \text { ); haematoma } \\
\text { expansion and cerebral oedema }(24 \mathrm{~h} \text { and } 72 \mathrm{~h}) \text {; death, } \\
\text { functional status, and QoL at discharge and at } 1 \text { and } \\
3 \text { months }\end{array}$ & $\begin{array}{l}\mathrm{HS}(<6 \mathrm{~h}) \text {, age }>18 \text { years, } \\
\text { systolic BP } 150-220 \mathrm{~mm} \mathrm{Hg}\end{array}$ & $\begin{array}{l}\text { Planned: } 2800 \\
\text { Actual: } 450 \\
\text { Recruiting }\end{array}$ \\
\hline SCAST (2005-ongoing) $)^{74}$ & $\begin{array}{l}\text { Randomised, double-blind, } \\
\text { placebo-controlled }\end{array}$ & $\begin{array}{l}\text { Candesartan vs } \\
\text { placebo }\end{array}$ & $\begin{array}{l}\text { Primary: death or disability and combination of vascular } \\
\text { death, myocardial infarction, or stroke ( } 6 \text { months) } \\
\text { Secondary: functional status and QoL at discharge and at } \\
6 \text { months }\end{array}$ & $\begin{array}{l}\text { Stroke }(<30 \mathrm{~h}) \text {, age }>18 \text { years, } \\
\text { systolic } \mathrm{BP} \geq 140 \mathrm{~mm} \mathrm{Hg}\end{array}$ & $\begin{array}{l}\text { Planned: } 2500 \\
\text { Actual: } 1371 \\
\text { Recruiting }\end{array}$ \\
\hline $\begin{array}{l}\text { ASA }=\text { American Stroke Assoc } \\
\text { INTERACT } 2=\text { Second Intensi } \\
\text { More information is availabl }\end{array}$ & $\begin{array}{l}\text { Elood Pressure Reduction in } \\
\text { in references } 71 \text { and } 77 \text {. For up }\end{array}$ & ed information on tria & $\begin{array}{l}\text { ke Antihypertensives Collaborative Study. ENOS=Efficacy of } \mathrm{Ni} \\
\text { I. QoL=quality of life. SCAST=Scandinavian Candesartan Acute } S \\
\text { registration numbers provided, readers can search using the we }\end{array}$ & or trial number provide & $\begin{array}{l}\text { lagic stroke. } \\
\text { could not be found } \\
\text { ference list. }\end{array}$ \\
\hline
\end{tabular}

between these two groups in baseline disease severity or risk of mortality on admission. In multivariable-adjusted analyses, the risk of in-hospital mortality was higher (OR 1.7; 95\% CI 1.3-2.2) among patients treated with nitroprusside compared with those who received nicardipine. Among patients in the two groups who were discharged alive, length and costs of hospitalisation were similar. ${ }^{89}$ Sublingual nifedipine should never be used because of the risk of abrupt hypotension, reactive overstimulation of the sympathetic nervous system, and because short-acting nifedipine can cause myocardial infarction in patients with coronary artery disease. ${ }^{76-84}$ Oral nimodipine might be indicated in patients with aneurysmal subarachnoid haemorrhage..$^{62,64}$

\section{Future directions and conclusions}

Globally, there were 16 million first-ever strokes in 2005, and this number is predicted to rise to 18 million and 23 million in 2015 and 2030, respectively. ${ }^{2}$ Ageing of populations and a redistribution of cardiovascular risk factors with economic development explain the worldwide increase in stroke risk and the transition from haemorrhagic to ischaemic stroke. ${ }^{90}$ High blood pressure is the predominant underlying risk factor. Increasing the control rates of hypertension, particularly in low-income or middle-income countries where more than $80 \%$ of the stroke mortality occurs, ${ }^{1,2}$ is therefore of paramount importance. Making antihypertensive drugs available and affordable is a high priority for the prevention of stroke. Strategies with the goal to produce an overall downward shift in the blood-pressure distribution of the population, along with interventions to improve diets ${ }^{91,92}$ and to reduce numbers of people who are overweight, ${ }^{93}$ smoke, ${ }^{94,95}$ and have hyper- cholesterolaemia, ${ }^{96,97}$ are likely to yield the greatest decrease in the global burden of stroke.

Even with the best possible prevention, many patients will still have a stroke. Alteplase, aspirin, and decompressive surgery for ischaemic stroke are proven interventions in acute stroke that are used in clinical practice. ${ }^{98}$ By contrast, the evidence for management of blood pressure in patients with acute stroke remains incomplete and contradictory. ${ }^{4-6}$ Most of these recommendations for management of blood pressure in acute stroke are based on expert opinion and general principles identified in observational studies or in small clinical trials, which mostly have intermediate outcomes. Specialised care in stroke units includes monitoring of blood pressure, which can reduce post-stroke mortality and disability by about $20 \% .{ }^{99}$ The introduction of stroke units should become a health-care priority, ${ }^{98}$ particularly in middle-income countries with high death rates due to stroke, such as northern China. ${ }^{100,101}$

Another matter to resolve is the extent to which characteristic blood-pressure profiles might beindependent predictors of stroke outcome and might inform therapeutic decisions. In an analysis of 793 patients enrolled in ECASS-II, ${ }^{102}$ blood pressure was measured every $15 \mathrm{~min}$ during the first $2 \mathrm{~h}$, then every $30 \mathrm{~min}$ during the next $8 \mathrm{~h}$, and thereafter at $1 \mathrm{~h}$ intervals. High baseline, high maximum and mean levels, and high variability of systolic blood pressure all predicted an unfavourable outcome. ${ }^{102}$ The blood-pressure readings in ECAS-II were obtained by conventional sphygmomanometry at the hemiparetic arm. ${ }^{102}$ Future studies should make use of automated techniques of blood-pressure measurement. To our knowledge, none of the ongoing trials on blood-pressure intervention in acute stroke uses this state-of-the-art 


\section{Search strategy and selection criteria}

References for this Review were identified by systematically searching the table of contents of journals that publish clinical research on hypertension or cerebrovascular disease (January, 2000, until January, 2009). Papers were also identified through searches of PubMed with the search terms "blood pressure," "hypertension", "stroke", "acute stroke", "haemorrhagic stroke", "ischaemic stroke", or any combination of these index terms. Only papers published in English were reviewed. We also checked the reference lists of review papers for updates of clinical trials and guidelines. We searched PubMed and Google with the acronyms of trials due to be published in 2007, 2008, or 2009 . We searched the websites of professional organisations for guidelines. $\mathrm{HZ}$ searched Chinese publications for epidemiological studies and clinical trials on stroke. We maintained a Reference Manager database (version 12; Thomson Reuters, NY, USA), which included all articles we cited in our previous publications on stroke ${ }^{3}$ and which we updated with potentially relevant papers until May, 2009. We included longitudinal studies focusing on the association of the outcome after stroke with blood pressure, ongoing trials in acute stroke, and clinical and experimental studies that, in our opinion, contributed to a better understanding of the acute hypertensive response. We excluded trials of prostacyclin (PGI2), magnesium sulphate, naftidrofuryl, and piracetam.

approach. ${ }^{103}$ More studies also need to investigate whether the clinical benefits of treating the acute hypertensive response in patients with stroke are drug specific.

In conclusion, more than $50 \%$ of all patients with acute stroke have an acute hypertensive response, which is associated with poor prognosis. Lowering blood pressure in such patients by intravenous or oral treatment is feasible, has little risk, and has a low cost. Pending confirmation in ongoing trials, ${ }^{70,75}$ which include patients with ischaemic or haemorrhagic stroke or both stroke subtypes (table 4), and pending widespread adoption of the results hoped for, lowering blood pressure in patients with new-onset stroke might translate into major absolute benefit.

\section{Contributors}

VT, HZ, and JAS searched the literature and wrote the first draft of the paper. JAS did the statistical analysis and TR drew the figures. All authors commented on the final draft.

\section{Conflicts of interest}

JAS consulted and received funding for studies, seminars, and travel from AstraZeneca, Daiichi-Sankyo, Ferrer, Mitsubishi Tanabe Pharma, Novartis, Pfizer, and Sigma-Tau. VT, HZ, and TR have no conflicts of interest.

\section{Acknowledgments}

The European Union (grants IC15-CT98-0329-EPOGH, LSHM-CT-2006-037093 InGenious Hyper-Care, and HEALTH-F4-2007-201550 HyperGenes), the Fonds voor Wetenschappelijk Onderzoek Vlaanderen, the Ministry of the Flemish Community, Brussels, Belgium (grants G.0424.03, G.0575.06 and G.0575.06), and the University of Leuven, Belgium (grants OT/00/25 and OT/05/49) gave support to the Studies Coordinating Centre. The Bilateral Scientific and Technological Collaboration between China and
Flanders, Ministry of the Flemish Community, Brussels (grant BIL02/10) supported the fellowship of HZ in Leuven. The authors gratefully acknowledge the expert assistance of Sandra Covens and Ya Zhu (Studies Coordinating Centre, Leuven, Belgium).

References

1 Lopez AD, Mathers CD, Ezzqati M, Jamison DT, Murray CJL. Global and regional burden of disease and risk factors, 2001: systematic analysis of population health data. Lancet 2006; 367: $1747-57$.

2 Strong K, Mathers C, Bonita R. Preventing stroke: saving lives around the world. Lancet Neurol 2007; 6: 182-87.

3 Zhang H, Thijs L, Staessen JA. Blood pressure lowering for the primary and secondary prevention of stroke. Hypertension 2006; 48: 187-95.

4 Qureshi AI. Acute hypertensive response in patients with stroke. Pathophysiology and management. Circulation 2008; 118: 176-87.

5 Mullen MT, McKinney JS, Kasner SE. Blood pressure management in acute stroke. J Hum Hypertens 2009; 23: 559-69.

6 Aiyagari V, Gorelick PB. Management of blood pressure for acute and recurrent stroke. Stroke 2009; 40: 2251-56.

7 Willmot M, Leonardi-Bee J, Bath PM. High blood pressure in acute stroke and subsequent outcome. A systematic review. Hypertension 2004; 43: 18-24.

8 Bath P, Chalmers J, Powers W, et al. International Society of Hypertension (ISH): statement on the management of blood pressure in acute stroke. J Hypertens 2003; 21: 665-72.

9 Qureshi AI, Ezzeddine MA, Nasar A, et al. Prevalence of elevated blood pressure in 563704 adult patients with stroke presenting to the ED in the United States. Am J Emerg Med 2007; 25: 32-38.

10 Leonardi-Bee J, Bath PMW, Phillips SJ, Sandercock PAG; for the IST Collaborative Group. Blood pressure and clinical outcomes in the International Stroke trial. Stroke 2002; 33: 1315-20.

11 CAST (Chinese Acute Stroke Trial) Collaborative Group. CAST: randomised placebo-controlled trial of early aspirin use in 20000 patients with acute ischaemic stroke. Lancet 1997; 349: 1641-49.

12 Rodríguez-Yáñez M, Castellanos M, Blanco M, et al. New-onset hypertension and inflammatory response/poor outcome in acute ischemic stroke. Neurology 2006; 67: 1973-78.

13 Boreas AMHP, Lodder J, Kessels F, de Leeuw PW, Troost J. Predictors of poststroke blood pressure level and course. J Stroke Cerebrovasc Dis 2001; 10: 85-91.

14 Toyoda K, Okada Y, Jinnouchi J, et al. High blood pressure in acute ischemic stroke and underlying disorders. Cerebrovasc Dis 2006; 22: 355-61.

15 Fodstad H, Kelley PJ, Buchfelder M. History of the Cushing reflex. Neurosurgery 2006; 59: 1132-37.

16 Chamorro A, Amaro S, Vargas M, et al. Catecholamines, infection, and death in acute ischemic stroke. J Neurol Sci 2007; 252: 29-35.

17 Dütsch M, Burger M, Dörfler C, Schwab S, Hilz MJ. Cardiovascular autonomic function in poststroke patients. Neurology 2007; 69: 2249-55.

18 Christensen H, Meden P, Overgaard K, Boysen G. The course of blood pressure in acute stroke is related to the severity of the neurological deficits. Acta Neurol Scand 2002; 106: 142-47.

19 Abboud H, Labreuche J, Plouin F, Amarenco P; for the GENIC Investigators. High blood pressure in early stroke: a sign of a poor outcome? J Hypertens 2006; 24: 381-86.

20 Jensen MB, Yoo B, Clarke WR, Davis PH, Adams HR Jr. Blood pressure as an independent prognostic factor in acute ischemic stroke. Can J Neurol Sci 2006; 33: 34-38.

21 Yong M, Diener HC, Kaste M, Mau J. Characteristics of blood pressure profiles as predictors of long-term outcome after acute ischemic stroke. Stroke 2005; 36: 2619-25.

22 Toyoda K, Fujimoto S, Kamouchi M, Iida M, Okada Y. Acute blood pressure levels and neurological deterioration in different subtypes of ischemic stroke. Stroke 2009; 40: 2585-88.

23 Sweileh WM, Sawalha AF, Al-Aqad SM, Zyoud SH, Al-Jabi SW. Predictors of in-hospital mortality after acute stroke: impact of gender. Int J Clin Exp Med 2009; 2: 41-47.

24 Okumura K, Ohya Y, Maehara A, Wakugami K, Iseki K, Takishita S. Effects of blood pressure levels on case fatality after acute stroke. J Hypertens 2005; 23: 1217-23. 
25 Ahmed N, Wahlgren G, Brainin M, et al. Relationship of blood pressure, antihypertensive therapy, and outcome in ischemic stroke treated with intravenous thrombolysis. Retrospective analysis from Safe Implementation of Thrombolysis in Stroke-International Stroke Thrombolysis Register (SITS-ISTR). Stroke 2009; 40: 2442-49.

26 Zhang Y, Reilly KH, Tong W, et al. Blood pressure and clinical outcome among patients with acute stroke in Inner Mongolia, China. J Hypertens 2008; 26: 1446-52.

27 Astrup J, Siesjö BK, Symon L. Thresholds in cerebral ischemiathe ischemic penumbra. Stroke 1981; 12: 723-25.

28 Olsen TS, Larsen B, Herning M, Skriver EB, Lassen NA. Blood flow and vascular reactivity in collaterally perfused brain tissue. Evidence of an ischemic penumbra in patients with acute stroke. Stroke 1983; 14: $332-41$.

29 Hayashi S, Nehls DG, Kieck CF, Vielma J, DeGirolami U, Crowell RM. Beneficial effects of induced hypertension on experimental stroke in awake monkeys. J Neurosurg 1984; 60: 151-57.

30 Drummond JC, Oh YS, Cole DJ, Shapiro HM.

Phenylephrine-induced hypertension reduces ischemia following middle cerebral artery occlusion in rats. Stroke 1989; 20: 1538-44.

31 Mistri AK, Robinson TG, Potter JF. Pressor therapy in acute ischemic stroke. Systematic review. Stroke 2006; 37: 1565-71.

32 Meier F, Wessel G, Thiele R, Gottschild D, Brandstätt H. Induced hypertension as an approach to treating acute cerebrovascular ischaemia: possibilities and limitations. Exp Pathol 1991; 42: 257-63.

33 Rordorf G, Cramer SC, Efird JT, Schwamm LH, Buonanno F, Koroshetz WJ. Pharmacological elevation of blood pressure in acute stroke. Clinical effects and safety. Stroke 1997; 28: 2133-38.

34 Rordorf G, Koroshetz WJ, Ezzeddine MA, Segal AZ, Buonanno FS. A pilot study of drug-induced hypertension for treatment of acute stroke. Neurology 2001; 56: 1210-13.

35 Duke BJ, Breeze RE, Rubenstein D, Tranmer BI, Kindt GW. Induced hypervolemia and inotropic support for acute cerebral arterial insufficiency: an underused therapy. Surg Neurol 1998; 49: $51-57$.

36 Saxena R, Wijnhoud AD, Carton H, et al. Controlled safety study of a hemoglobin-based oxygen carrier, DCLHb, in acute ischemic stroke. Stroke 1999; 30: 993-96.

37 Hillis AE, Barker PB, Beauchamp NJ, Winters BD, Mirski M, Wityk RJ. Restoring blood pressure reperfused Wernicke's area and improved language. Neurology 2001; 56: 670-72.

38 Hillis AE, Ulatowski JA, Barker PB, et al. A pilot randomized trial of induced blood pressure elevation: effects on function and focal perfusion in acute and subacute stroke. Cerebrovasc Dis 2003; 16: $236-46$

39 Hillis AE, Wityk RJ, Beauchamp NJ, Ulatowski JA, Jacobs MA, Barker PB. Perfusion-weighted MRI as marker of response to treatment in acute and subacute stroke. Neuroradiology 2004; 46: 31-39.

40 Hillis AE, Kane A, Tuffiash E, et al. Reperfusion of specific brain regions by raising blood pressure restores selective language functions in subacute stroke. Brain Lang 2001; 79: 495-510.

41 Oliveira-Filho J, Pedreira BB, Jesus PAP, Souza PEM, Bacellar AS. Pharmacologically-induced hypertension in a patient with vertebro-basilar territory ischemia associated with bilateral vertebral stenosis. Arq Neuropsiquiatr 2002; 60: 498-501 (in Portuguese).

42 Schwarz S, Georgiadis D, Aschoff A, Schwab S. Effects of induced hypertension on intracranial pressure and flow velocities of the middle cerebral arteries in patients with large hemispheric stroke. Stroke 2002; 33: 998-1004.

43 Marzan AS, Hungerbühler HJ, Studer A, Baumgartner RW, Georgiadis D. Feasibility and safety of norepinephrine-induced arterial hypertension in acute ischemic stroke. Neurology 2004; 62: 1193-95.

44 Koenig MA, Geocadin RG, de Grouchy M, et al. Safety of induced hypertension therapy in patients with acute ischemic stroke. Neurocrit Care 2006; 4: 3-7.

45 Potter JF, Robinson TG, Ford GA, et al. Controlling hypertension and hypotension immediately post-stroke (CHHIPS): a randomised, placebo-controlled, double-blind pilot trial. Lancet Neurol 2009; 8: $48-56$
46 Potter J, Mistri A, Brodie F, et al. Controlling hypertension and hypotension immediately post stroke (CHHIPS) - a randomised controlled trial. Health Technol Assess 2009; 13: 1-73.

47 Schrader J, Röthemeyer M, Lüders S, Kollmann K. Hypertension and stroke-rationale behind the ACCESS trial. Basic Res Cardiol 1998; 93 (suppl 2): 69-78.

48 Schrader J, Lüders S, Kulschewski A, et al. The ACCESS Study. Evaluation of acute candesartan cilexetil therapy in stroke survivors. Stroke 2003; 34: 1699-703.

49 National Research Register. Controlling hypertension and hypotension immediately post-stroke (CHHIPS) trial. N0484128008. https://portal.nihr.ac.uk/Profiles/NRR.aspx?Publication ID $=$ N0484128008 (accessed Aug 23, 2009)

50 Anderson CS, Huang Y, Wang JG, et al. Intensive blood pressure reduction in acute cerebral haemorrhage trial (INTERACT): a randomised pilot trial. Lancet Neurol 2008; 7: 391-99.

51 Intensive blood pressure reduction in acute cerebral haemorrhage. NCT00226096. http://www.clinicaltrials.gov/ct2/show/ NCT00226096 (accessed Aug 5, 2009).

52 Qureshi AI. Antihypertensive treatment of acute cerebral hemorrhage (ATACH): rationale and design. Neurocrit Care 2007; 6: 56-66.

53 Qureshi AI. Antihypertensive treatment of acute cerebral hemorrhage (ATACH) trial. In: Late-breaking science abstracts. New Orleans: American Heart Association and American Stroke Association, 2008. LBP1 (abstract)

54 Antihypertensive treatment in acute cerebral hemorrhage (ATACH). NCT00415610. http://www.clinicaltrials.gov/ct2/show/NCT00415610 (accessed Aug 5, 2009).

55 The Blood Pressure in Acute Stroke Collaboration (BASC). Vasoactive drugs for acute stroke. Cochrane Database Syst Rev 2000; 4: CD002839.

56 Barer DH, Cruickshank JM, Ebrahim SB, Mitchell JR. Low dose beta blockade in acute stroke ("BEST" trial): an evaluation. BMJ 1988; 296: 737-41.

57 Rashid P, Weaver C, Leonardi-Bee J, Bath F, Fletcher S, Bath P. The effects of transdermal glyceryl trinitrate, a nitrate oxide donor, on blood pressure cerebral and cardiac hemodynamics, and plasma nitric oxide levels in acute stroke. J Stroke Cerebrovasc Dis 2003; 12: $143-51$.

58 Bath PMW, Pathansali R, Iddenden R, Bath FJ. The effect of transdermal glyceryl trinitrate, a nitrate oxide donor, on blood pressure cerebral and platelet function in acute stroke. Cerebrovasc Dis 2001; 11: 265-72.

59 Bath PMW, Willmot M, Leonardi-Bee J, Bath-Hextall FJ. Nitric oxide donors (nitrates), L-arginine, or nitric oxide synthase inhibitors for acute stroke. Cochrane Database Syst Rev 2002; 4: CD000398.

60 Eames PJ, Robinson TG, Panerai RB, Potter JF. The systemic haemodynamic and cerebral autoregulatory effects of bendrofluazide in the subacute post-stroke period. J Hypertens 2004; 22: 2017-24.

61 Eames PJ, Robinson TG, Panerai RB, Potter JF. Bendrofluazide fails to reduce elevated blood pressure levels in the immediate post-stroke period. Cerebrovasc Dis 2005; 19: 253-59.

62 Dorhout Mees S, Rinkel GJE, Feigin VL, et al. Calcium antagonists for aneurysmal subarchnoid haemorrhage. Cochrane Database Syst Rev 2007; 3: CD000277.

63 Pickard JD, Murray GD, Illingworth R, et al. Effect of oral nimodipine on cerebral infarction and outcome after subarachnoid haemorrhage: British aneurysm nimodipine trial. BMJ 1989; 298: 636-42.

64 Sabbatini M, Strocchi P, Amenta F. Nicardipine and treatment of cerebrovascular diseases with particular reference to hypertension-related disorders. Clin Exp Hypertens 1995; 17: 719-50.

65 Amenta F, Lanari A, Mignini F, Solvesrelli G, Traini E, Tomassi D. Nicardipine use in cerebrovascular disease: a review of controlled clinical trials. J Neurol Sci 2009; 283: 219-23.

66 Acute Candesartan Cilexetil Outcomes Stroke Trial (ACCOST). NCT00108706. http://www.clinicaltrials.gov/ct2/show/ NCT00108706 (accessed Aug 5, 2009).

67 Blood pressure lowering in acute stroke trial (BLAST). NCT00627991. http://www.clinicaltrials.gov/ct2/show/ NCT00627991 (accessed Aug 5, 2009).

68 IV double and triple concentrated nicardipine for stroke and $\mathrm{ICH}$. NCT00325793. http://www.clinicaltrials.gov/ct2/show/ NCT00325793 (accessed Aug 5, 2009). 
69 Stroke Trials Registry. http://www.strokecenter.org/trials (accessed Aug 5, 2009).

70 The COSSACS Trial Group. COSSACS (Continue Or Stop post-Stroke Antihypertensives Collaborative Study): rationale and design. J Hypertens 2005; 23: 455-58.

71 The ENOS Investigators. Glyceryl trinitrate vs. control, and continuing vs. stopping temporarily antihypertensive therapy, in acute stroke: rationale and design of the Efficacy of Nitric Oxide in Stroke (ENOS) trial (ISRCTN99414122). Int J Stroke 2006; 1: 245-49.

72 Efficacy of nitric oxide in stroke. ISRCTN99414122. http://www. controlled-trials.com/ISRCTN99414122/99414122 (accessed Aug 5, 2009).

73 The Second Intensive Blood Pressure Reduction in Acute Cerebral Haemorrhage Trial (INTERACT2). NCT00716079. http://www. clinicaltrials.gov/ct2/show/NCT00716079 (accessed Aug 5, 2009).

74 Scandinavian Candesartan Acute Stroke Trial. ISRCTN13643354. http://www.controlled-trials.com/ISRCTN13643354/13643354 (accessed Aug 5, 2009).

75 Major ongoing stroke trials. Stroke 2006; 37: e27-e35.

76 The European Stroke Initiative executive committee and the EUSI writing committee. European stroke initiative recommendations fo stroke management-update 2003. Cerebrovasc Dis 2003; 16: 311-37.

77 Stroke Foundation New Zealand. Life after stroke: New Zealand guideline for management of stroke. Best practice evidence-based guideline. Wellington, New Zealand: 2003. http://www.nzgg.org. nz/guidelines/0037/ACF291F.pdf (accessed Aug 18, 2009).

78 Ng PW, Huang CY, Cheung RTF, et al. Consensus statement on ischaemic stroke care in Hong Kong. Hong Kong Med J 2004; 10: $124-29$.

79 Broderick J, Connolly S, Feldmann E, et al. Guidelines for the management of spontaneous intracerebral henmorrhage in adults2007 update. A guideline from the American Heart Association/ American Stroke Association Stroke Council, High Blood Research Council, and the Quality of Care and Outcomes in Research Interdisciplinary Working Group. Stroke 2007; 38: 2001-23.

80 National Stroke Foundation. Clinical guidelines for acute stroke management 2007. http://www.nhmrc.gov.au/publications/ synopses/_files/cp109.pdf (accessed July 4, 2009).

81 National Collaborating Centre for Chronic Conditions. Stroke: national clinical guideline for diagnosis and initial management of acute stroke and transient ischaemic attack (TIA). London, United Kingdom: Royal College of Physicians, 2008. http://www.rcplondon. ac.uk/pubs/brochure.aspx?e=254 (accessed July 31, 2009)

82 American Academy of Neurology. Stroke Coding Guide of the American Academy of Neurology 2008. http://www.stroke-site.org/ guidelines/stroke_coding.html (accessed July 4, 2009).

83 Adams HP Jr, del Zoppo G, Alberts MJ, et al. Guidelines for the early management of adults with ischemic stroke. A guideline from the American Heart Association/American Stroke Association Stroke Council, Clinical Cardiology Council, Cardiovascular Radiology and Intervention Council, and the Atherosclerotic Peripheral Vascular Disease and Quality of Care Outcomes in Research Interdisciplinary working groups. Circulation 2007; 115: e478-e534.

84 The European Stroke Organisation (ESO) Executive Committee and the ESO Writing Committee. Guidelines for management of ischaemic stroke and transient ischaemic attack 2008. Cerebrovasc Dis 2008; 25: 457-507.
85 Rao M. China Guidelines for Cerebrovascular Disease Prevention and Treatment. Beijing, China: People's Medical Publishing House, 2007.

86 Rothwell PM, Howard SC, Spence JD; for the Carotid Endarterectomy Trialists' Collaboration. Relationship between blood pressure and stroke risk in patients with symptomatic carotid occlusive disease. Stroke 2003; 34: 2583-92.

87 White RP, Markus HS. Impaired dynamic cerebral autoregulation in carotid artery stenosis. Stroke 1997; 28: 1340-44.

88 Paciaroni M, Agnelli G, Caso V, et al. Effect of carotid stenosis on the prognostic value of admission blood pressure in patients with acute ischemic stroke. Atherosclerosis 2009; published online April 5. DOI:10.1016/j.atherosclerosis.2009.03.036.

89 Suri MF, Vazquez G, Ezzeddine MA, Qureshi AI. A multicenter comparison of outcomes associated with intravenous nitroprusside and nicardipine treatment among patients with intracerebral hemorrhage. Neurocrit Care 2009; 11: 50-55.

90 Yang G, Kong L, Zhao W, et al. Health System Reform in China 3. Emergence of chronic non-communicable diseases in China. Lancet 2008; 372: 1697-705.

91 He FJ, Nowson CA, MacGregor GA. Fruit and vegetable consumption and stroke: meta-analysis of cohort studies. Lancet 2006; 367: 320-26.

92 Ding EL, Mozaffarian D. Optimal dietary habits for the prevention of stroke. Semin Neurol 2006; 26: 11-23.

93 Douketis JD, Sharma AM. Obesity and cardiovascular disease: pathogenetic mechanisms and potential benefits of weight reduction. Semin Vasc Med 2005; 5: 25-33.

94 Hurley SF. Short-term impact of smoking cessation on myocardial infarction and stroke hospitalisations and costs in Australia. Med J Aust 2005; 183: 13-17.

95 Iso H, Date C, Yamamoto A, et al. Smoking cessation and mortality from cardiovascular disease among Japanese men and women. The JACC Study. Am J Epidemiol 2005; 161: 170-79.

96 Asia Pacific Cohort Studies Collaboration. Cholesterol, coronary heart disease, and stroke in the Asia Pacific Region. Int I Epidemiol 2003; 32: 563-72.

97 Amarenco P, Benavente O, Goldstein DS, et al. Results of the stroke prevention by aggressive reduction in cholesterol levels (SPARCL) trial by stroke subtype. Stroke 2009; 40: 1405-09.

98 Donnan GA, Fisher M, Macleod M, Davis SM. Stroke. Lancet 2008; 371: 1612-23.

99 Stroke Unit Trialists' Collaboration. Organised inpatient (stroke unit) care for stroke. Cochrane Database Syst Rev 2007; 4: CD000197.

100 Truelsen T, Bonita R. Epidemiological transition of stroke in China? Stroke 2008; 39: 1653-54.

101 Liu M, Wang WZ, Zhang SH, Kong LZ. Stroke in China: epidemiology, prevention, and management strategies. Lancet Neurol 2007; 6: 456-64.

102 Yong M, Kaste M. Association of characteristics of blood pressure profiles and stroke outcomes in the ECASS-II trial. Stroke 2008; 39: $366-72$.

103 Staessen JA, O’Brien ET, Thijs L, Fagard RH. Modern approaches to blood pressure measurement. Occup Environ Med 2000; 57: 510-20. 


\section{THE LANCET Neurology}

\section{Supplementary webappendix}

This webappendix formed part of the original submission and has been peer reviewed. We post it as supplied by the authors.

Supplement to: Tikhonoff V, Zhang H, Richart T, Staessen JA. Blood pressure as a prognostic factor after acute stroke. Lancet Neurol 2009; 8: 938-48. 
Webtable 1: Current guidelines for the management of increased blood pressure in acute ischaemic stroke

\begin{tabular}{|c|c|c|}
\hline & Indications for lowering blood pressure & Recommended drugs \\
\hline \multirow[t]{2}{*}{$\begin{array}{l}\text { European Stroke Initiative } \\
\text { recommendations for stroke } \\
\text { management }\left(2003 ; ;^{1} \text { updated in }\right. \\
2008 \text { by the European Stroke } \\
\text { Organisation })^{2}\end{array}$} & $\begin{array}{l}\mathrm{SBP}>220 \mathrm{~mm} \mathrm{Hg} \text { or DBP } 120-140 \mathrm{~mm} \mathrm{Hg} \\
\text { (on repeated measurement); heart failure; aortic } \\
\text { dissection; acute myocardial infarction; hypertensive } \\
\text { encephalopathy; acute renal failure; thrombolysis and } \\
\mathrm{SBP}>185 \mathrm{~mm} \mathrm{Hg} \text { or DBP }>110 \mathrm{~mm} \mathrm{Hg}\end{array}$ & $\begin{array}{l}\text { Captopril } 6 \cdot 25-12 \cdot 5 \mathrm{mg} \text { po, labetalol } 5-20 \mathrm{mg} \text { iv, urapidil } 10-50 \mathrm{mg} \text { iv (followed by } 4-8 \mathrm{mg} / \mathrm{h} \text { ), clonidine } 0 \cdot 15-0 \cdot 3 \mathrm{mg} \text { sc or iv, dihydralazine } 5 \\
\mathrm{mg} \text { plus metoprolol } 10 \mathrm{mg} \text { iv }\end{array}$ \\
\hline & $\mathrm{DBP} \geq 140 \mathrm{~mm} \mathrm{Hg}$ & Nitroglycerin $5 \mathrm{mg}$ iv (followed by $1-4 \mathrm{mg} / \mathrm{h}$ ), sodium nitroprusside $0.5-10 \mu \mathrm{g} / \mathrm{kg} / \mathrm{min}$ iv \\
\hline $\begin{array}{l}\text { AHA/ASA Scientific Statement. } \\
\text { Guidelines for the early } \\
\text { management of adults with } \\
\text { ischaemic stroke }(2007)^{3}\end{array}$ & $\begin{array}{l}\mathrm{SBP}>220 \mathrm{~mm} \mathrm{Hg} \text { or DBP }>120 \mathrm{~mm} \mathrm{Hg} \text {; pulmonary } \\
\text { oedema; aortic dissection; acute myocardial } \\
\text { infarction; hypertensive encephalopathy; } \\
\text { thrombolysis and } \mathrm{SBP}>185 \mathrm{~mm} \text { Hg or DBP }>110 \\
\mathrm{~mm} \mathrm{Hg}\end{array}$ & $\begin{array}{l}\text { Lower BP by } 15 \% \text { within the first } 24 \mathrm{~h} \text {, labetalol } 10-20 \mathrm{mg} \text { iv over } 1-2 \mathrm{~min} \text { (repeat every } 10-20 \mathrm{~min} \text { to a maximum of } 300 \mathrm{mg} \text { ), nicardipine } 5 \\
\mathrm{mg} / \mathrm{h} \text { iv (titrate by increasing } 2.5 \mathrm{mg} / \mathrm{h} \text { every } 5-15 \mathrm{~min} \text { to maximum of } 15 \mathrm{mg} / \mathrm{h} \text { and at goal BP reduce to } 3 \mathrm{mg} / \mathrm{h} \text { ) }\end{array}$ \\
\hline $\begin{array}{l}\text { New Zealand guideline for } \\
\text { management of stroke }(2003)^{4}\end{array}$ & $\begin{array}{l}\mathrm{SBP}>220 \mathrm{~mm} \mathrm{Hg} \text { or } \mathrm{DBP}>120 \mathrm{~mm} \mathrm{Hg} \\
\text { thrombolysis and } \mathrm{SBP}>185 \mathrm{~mm} \mathrm{Hg} \text { or } \mathrm{DBP}>110 \\
\mathrm{~mm} \mathrm{Hg}\end{array}$ & Labetalol (dosage unspecified) \\
\hline \multirow[t]{2}{*}{$\begin{array}{l}\text { American Academy of Neurology } \\
\text { stroke coding guide }(2008)^{5}\end{array}$} & $\begin{array}{l}\mathrm{SBP}>220 \mathrm{~mm} \mathrm{Hg} \text { or DBP } 121-140 \mathrm{~mm} \mathrm{Hg} \text { or MAP } \\
>130 \mathrm{~mm} \mathrm{Hg} \text { ( } 2 \text { readings } 20 \text { min apart); heart failure, } \\
\text { aortic dissection, or acute myocardial infarction and } \\
\text { SBP } 185-220 \mathrm{~mm} \mathrm{Hg} \text { or DBP } 105-120 \mathrm{~mm} \mathrm{Hg} \text {; } \\
\text { thrombolysis and SBP }>185 \mathrm{~mm} \mathrm{Hg} \text { or DBP }>110 \\
\mathrm{~mm} \mathrm{Hg}\end{array}$ & $\begin{array}{l}\text { Labetalol } 10-20 \mathrm{mg} \text { iv over } 1-2 \mathrm{~min} \text { (repeat every } 10-20 \mathrm{~min} \text { to a maximum of } 300 \mathrm{mg} \text { ), enalapril } 1.25 \mathrm{mg} \text { iv over } 5 \mathrm{~min} \text { (to be repeated every } 6 \\
\mathrm{~h} ; 0.625 \mathrm{mg} \text { in the elderly) }\end{array}$ \\
\hline & $\mathrm{DBP}>140 \mathrm{~mm} \mathrm{Hg}$ (2 readings 5 min apart) & Sodium nitroprusside $0 \cdot 5-10 \mu \mathrm{g} / \mathrm{kg} / \mathrm{min}$ iv \\
\hline $\begin{array}{l}\text { NICE guideline for } \\
\text { diagnosis and initial management of } \\
\text { acute stroke and TIA }(2008)^{6}\end{array}$ & $\begin{array}{l}\text { Heart failure, aortic dissection, acute myocardial } \\
\text { infarction, hypertensive encephalopathy, acute renal } \\
\text { failure, preeclampsia/eclampsia and SBP }>200 \mathrm{~mm} \\
\mathrm{Hg} \text {; thrombolysis and SBP }>185 \mathrm{~mm} \mathrm{Hg} \text { or DBP } \\
>110 \mathrm{~mm} \mathrm{Hg}\end{array}$ & $\beta$ blockers (not further specified), calcium-channel blockers (not further specified) \\
\hline $\begin{array}{l}\text { Australian National Stroke } \\
\text { Foundation. Clinical guidelines for } \\
\text { acute stroke management }(2007)^{7}\end{array}$ & $\mathrm{SBP}>220 \mathrm{~mm} \mathrm{Hg}$ or $\mathrm{DBP}>120 \mathrm{~mm} \mathrm{Hg}$ & Lower BP no more than $10-20 \%$ \\
\hline China Guidelines for & $\mathrm{SBP}>220 \mathrm{~mm} \mathrm{Hg}$ or DBP $>120 \mathrm{~mm} \mathrm{Hg}$ &.. \\
\hline
\end{tabular}


cerebrovascular disease prevention

and treatment $(2007)^{8}$

haemorrhagic transformation and SBP $>180 \mathrm{~mm} \mathrm{H}$

or DBP $>105 \mathrm{~mm} \mathrm{Hg}$, reperfusion intervention and

SBP $>180 \mathrm{~mm} \mathrm{Hg}$ or DBP $>105 \mathrm{~mm} \mathrm{Hg}$

The Hong Kong Neurological

Society and Hong Kong Strok

Society consensus statement on

$\mathrm{SBP} \geq 220 \mathrm{~mm} \mathrm{Hg}$ or DBP $\geq 120 \mathrm{~mm} \mathrm{Hg}$ (on repeated

measurements $20 \mathrm{~min}$ apart) and hypertensive

emergency (heart failure or aortic dissection or

ischaemic stroke care in Hong Kong hypertensive encephalopathy)

$(2004)^{9}$

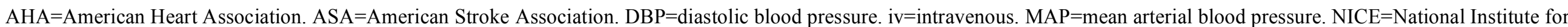

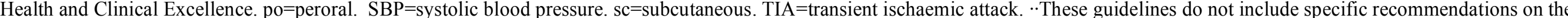
drugs to be used. 


\section{Webtable 2: Current guidelines for the management of increased blood pressure in acute haemorrhagic stroke}

\section{Indications for lowering blood pressure}

$\mathrm{SBP}>180 \mathrm{~mm}$ Hg or DBP $>105 \mathrm{~mm} \mathrm{Hg}$ (on repeated measurement)

European Stroke Initiative

recommendations for stroke management $(2003)^{1}$

\section{Recommended drugs}

Captopril 6.25-12.5 mg po, labetalol 5-20 mg iv, urapidil 10-50 mg iv (followed by 4-8 mg/h), clonidine $0 \cdot 15-0 \cdot 3 \mathrm{mg} \mathrm{sc}$ or iv, dihydralazine $5 \mathrm{mg}$ plus metoprolol $10 \mathrm{mg}$ iv

Sublingual nifedipine to be avoided
AHA/ASA Scientific Statement: guidelines for $\quad$ SBP $>200 \mathrm{~mm} \mathrm{Hg}$ or MAP $>150 \mathrm{mmHg}$; the management of spontaneous intracerebral haemorrhage in adults $(2007)^{10}$ increased $\mathrm{ICP}$ and $\mathrm{SBP}>180 \mathrm{~mm} \mathrm{Hg}$ or MAP

$>130 \mathrm{~mm} \mathrm{Hg} ; \mathrm{SBP}>180 \mathrm{~mm}$ Hg or MAP

$>130 \mathrm{~mm} \mathrm{Hg}$
Continuous iv infusion of labetalol $2 \mathrm{mg} / \mathrm{min}$ (up to $300 \mathrm{mg} / \mathrm{day}$ ) or esmolol 25 to $300 \mu \mathrm{g} / \mathrm{kg} / \mathrm{min}$ or hydralazine $1.5-5 \mu \mathrm{g} / \mathrm{kg} / \mathrm{min}$ or nicardipine $5-15 \mathrm{mg} / \mathrm{h}$ or nitroglycerin $20-400 \mu \mathrm{g} / \mathrm{min}$; to keep CPP $>60$ to $80 \mathrm{~mm} \mathrm{Hg}$ intermittent iv infusion of labetalol 5-20 mg every 15 min or esmolol $250 \mu \mathrm{g} / \mathrm{kg}$ or enalapril $0 \cdot 625-5 \mathrm{mg}$ every $6 \mathrm{~h}$ or hydralazine 5-20 mg every $30 \mathrm{~min}$ or continuous iv infusion as outlined above; intermittent or continuous iv infusion of medications (see above) until MAP $110 \mathrm{~mm} \mathrm{Hg}$ or target BP 160/90 mm Hg

New Zealand guideline for management of

stroke $(2003)^{4}$

China guideline for cerebrovascular disease

History of hypertension and MAP $\geq 130 \mathrm{mmHg}$

SBP $>200 \mathrm{~mm} \mathrm{Hg}$ or DBP $>110 \mathrm{~mm} \mathrm{Hg}$

(2008)

NICE guideline for

SBP $>200 \mathrm{~mm} \mathrm{Hg}$

diagnosis and initial management of acute

stroke and TIA $(2008)^{6}$

Australian National Stroke Foundation clinical guidelines for acute stroke

History of hypertension and

guidelines for acute stroke
management $(2007)^{7}$

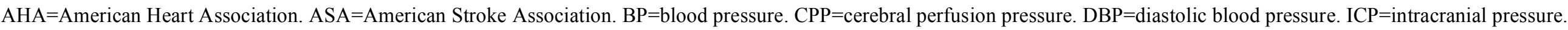

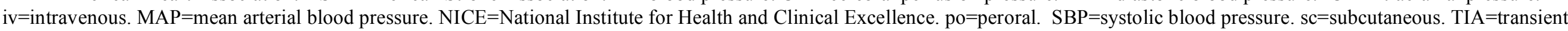
ischaemic attack. " These guidelines do not include specific recommendations on the drugs to be used.

\section{References}

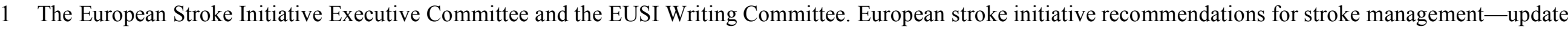
2003. Cerebrovasc Dis 2003; 16: 311-37.

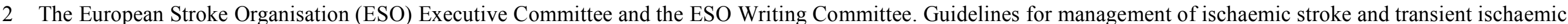
attack 2008. Cerebrovasc Dis 2008; 25: 457-507.

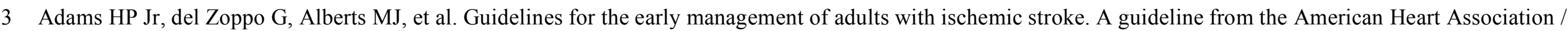

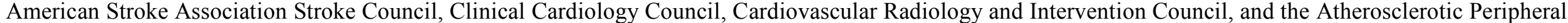
Vascular Disease and Quality of Care Outcomes in Research Interdisciplinary working groups. Circulation 2007; 115: e478-e534.

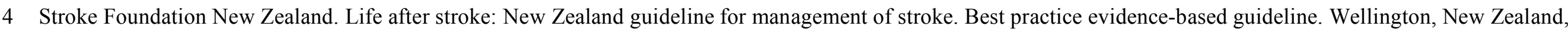
2003. http://nzgg.org.nz/guidelines/0037/ACF291F.pdf (accessed Aug 18, 2009). 
5 American Academy of Neurology. Stroke coding guide of the American Academy of Neurology 2008. http://www.stroke-site.org/guidelines/stroke coding.html (accessed July 4, 2009).

6 National Collaborating Centre for Chronic Conditions. Stroke: national clinical guideline for diagnosis and initial management of acute stroke and transient ischaemic attack (TIA). London, United Kingdom: Royal College of Physicians, 2008. http://www.rcplondon.ac.uk/pubs/brochure.aspx?e=254 (accessed July 31, 2009)

7 National Stroke Foundation. Clinical guidelines for acute stroke management, 2007. http://www.nhmrc.gov.au/publications/synopses/_files/cp109.pdf (accessed Aug 18, 2009).

8 Rao M. China guidelines for cerebrovascular disease prevention and treatment. Beijing, China: People's Medical Publishing House, 2007.

9 Ng PW, Huang CY, Cheung RTF, et al. Consensus statement on ischaemic stroke care in Hong Kong. Hong Kong Med J 2004 ; 10: 124-29.

10 Broderick J, Connolly S, Feldmann E, et al. Guidelines for the management of spontaneous intracerebral henmorrhage in adults-2007 update. A guideline from the American Heart Association/American Stroke Association Stroke Council, High Blood Research Council, and the Quality of Care and Outcomes in Research Interdisciplinary Working Group. Stroke 2007; 38: 2001-23. 